\title{
Local erosion rates versus active tectonics: Cosmic Ray Exposure modelling in Provence (south-east France)
}

Lionel Siame $^{\mathrm{a}^{*}}$, Olivier Bellier ${ }^{\mathrm{b}}$, Régis Braucher ${ }^{\mathrm{b}}$, Michel Sébrier ${ }^{\mathrm{c}}$, Marc Cushing ${ }^{\mathrm{d}}$, Didier Bourlès $^{\mathrm{b}}$, Bruno Hamelin ${ }^{\mathrm{b}}$, Emmanuel Baroux ${ }^{\mathrm{a}, \mathrm{e}}$, Beatrice de Voogd ${ }^{\mathrm{f}}$, Grant Raisbeck ${ }^{\mathrm{g}}$, Françoise Yiou $^{\mathrm{g}}$

${ }^{a}$ Orsayterre - FRE 2566 CNRS - Bât. 504-2 ${ }^{\circ}$, Université Paris-Sud, 91405 Orsay Cedex, France ${ }^{b}$ CEREGE (Centre Européen de Recherche et d'Enseignement des Géosciences de l'Environnement) - UMR CNRS 6635 Université Aix-Marseille III, BP 80, Europôle méditerranéen de l'Arbois, 13345 Aix-enProvence Cedex04, France ${ }^{c}$ Laboratoire de tectonique - UMR CNRS 7072 - Université Pierre et Marie Curie, T26-25, Case 129, 4, place Jussieu, 75252 Paris Cedex 05, France

${ }^{d}$ IRSN (Institut de Radioprotection de Sûreté Nucléaire) - Bureau d'Evaluation des Risques Sismiques pour la Sûreté des Installations Nucléaires - B.P.1792262 FONTENAY-AUX-ROSES Cedex

epresent adress: Sezione Roma 1, Istituto Nazionale di Geofisica e Vulcanologia (INGV) - Via di Vigna Murata, 60500143 Roma Italy

${ }^{f}$ Géologie et UMR5831 - Laboratoire de Géophysique, avenue de l'Université, B.P.1155 64013 Pau Cedex ${ }^{g}$ Centre de Spectromérie Nucléaire et de Spectrométrie de Masse (IN2P3 - CNRS), Bât. 108 Université Paris-Sud, 91405 Orsay Cedex, France

Word count on the main text: 7350 (9.8 pages)

Number of references: 45 (1.3 pages)

Word count on the abstract: 211 (1 page)

1 table -8 figures

*Corresponding author, Tel: +33-1-69156754; E-mail address: siame@geol.u-psud.fr 


\title{
Local erosion rates versus active tectonics: Cosmic Ray Exposure modelling in Provence (south-east France)
}

\author{
Lionel Siame $^{\mathrm{a}^{*}}$, Olivier Bellier ${ }^{\mathrm{b}}$, Régis Braucher ${ }^{\mathrm{b}}$, Michel Sébrier ${ }^{\mathrm{c}}$, Marc Cushing ${ }^{\mathrm{d}}$, Didier \\ Bourlès $^{\mathrm{b}}$, Bruno Hamelin ${ }^{\mathrm{b}}$, Emmanuel Baroux ${ }^{\mathrm{a}, \mathrm{e}}$, Beatrice de Voogd ${ }^{\mathrm{f}}$, Grant Raisbeck ${ }^{\mathrm{g}}$, \\ Françoise Yiou $^{\mathrm{g}}$ \\ ${ }^{a}$ Orsayterre - FRE 2566 CNRS - Bât. 504-2, Université Paris-Sud, 91405 Orsay Cedex, France \\ ${ }^{b}$ CEREGE (Centre Européen de Recherche et d'Enseignement des Géosciences de l'Environnement) - UMR CNRS 6635 - \\ Université Aix-Marseille III, BP 80, Europôle méditerranéen de l'Arbois, 13345 Aix-enProvence Cedex04, France \\ ${ }^{c}$ Laboratoire de tectonique - UMR CNRS 7072 - Université Pierre et Marie Curie, T26-25, Case 129, 4, place Jussieu, \\ 75252 Paris Cedex 05, France \\ ${ }^{d}$ IRSN (Institut de Radioprotection de Sûreté Nucléaire) - Bureau d'Evaluation des Risques Sismiques pour la Sûreté des \\ Installations Nucléaires - B.P.1792262 FONTENAY-AUX-ROSES Cedex \\ epresent adress: Sezione Roma 1, Istituto Nazionale di Geofisica e Vulcanologia (INGV) - Via di Vigna Murata, 60500143 \\ Roma Italy \\ ${ }^{f}$ Géologie et UMR5831 - Laboratoire de Géophysique, avenue de l'Université, B.P.1155 64013 Pau Cedex \\ ${ }^{g}$ Centre de Spectromérie Nucléaire et de Spectrométrie de Masse (IN2P3 - CNRS), Bât. 108 Université Paris-Sud, 91405
}

Orsay Cedex, France

\begin{abstract}
Since the past decade, in situ-produced cosmogenic nuclides revolutionise the study of landscape evolution. In particular, numerous studies have demonstrated that, in active tectonic settings, cosmic ray exposure dating of deformed or displaced geomorphic features allows to quantify long-term deformation rates. In western European countries, erosion due to climatically-driven processes and human activities is probably the factor that mostly limits the accuracy of exposure ages and landscape modification rates. In this study, we present the results of a depth-profiling technique applied to alluvial terraces located along the Rhône and the Moyenne Durance rivers. The expected decrease with depth of the measured ${ }^{10} \mathrm{Be}$ concentrations has been modelled using a khi-square inversion method in order to constrain the exposure history of the alluvial sediments. The results suggest that (1) over the Quaternary, the local surface erosion rates including both regional uplift and climaticallydriven processes acting on landforms are on the order of $30 \mathrm{~m} / \mathrm{Myr}$ in south-eastern France, and (2) providing a fairly good bracketing of the exposure age, the modelled abandonment age of alluvial terraces affected by the Moyenne Durance Fault allows estimating incision rates, comparing the alluvial terrace elevations with topographic river profiles, and a minimum vertical slip rate value of roughly $0.02 \mathrm{~mm} / \mathrm{yr}$ for the southern segment of the Moyenne Durance Fault.
\end{abstract}

Keywords: Be-10, cosmogenic nuclides, erosion rates, active faults, SE-France

*Corresponding author, Tel: +33-1-69156754; E-mail address: siame@geol.u-psud.fr 


\section{Introduction}

Improving the identification and characterisation of active deformation in low-seismicity regions is a key task to better address the seismogenic potential of active faults. In south-eastern France, a low seismicity region, earthquake activity (Fig. 1) is the result of the NNW-SSE oriented convergence between the Eurasian and African plates at a rate of 5 to $9 \mathrm{~mm} / \mathrm{yr}$ [1]. Since this convergence has to be distributed across several tectonic structures spread over $2000 \mathrm{~km}$, roughly from Belgium to southern Morocco, the slip rates of individual faults are expected to be low (i.e., much lower than $1 \mathrm{~mm} / \mathrm{yr}$ ). In regions of low deformation rates, the geomorphic signal of tectonic activity may be subdued and highly modified by climatic and human activities. In addition, in Western Europe, the relative contribution of structural inheritance versus active tectonics to landscape evolution is poorly understood, because of the poor time control on this landscape evolution. In such tectonic settings, detecting active deformation that may lead to destructive earthquakes thus requires innovative research methodologies that will supply basic data for more accurate assessment of seismic hazard, suiting the western European climate, its slowly deforming faults and heavily anthropogenically-modified areas.

Since the past decade, in situ-produced cosmogenic nuclides revolutionise the study of landscape development. Indeed, numerous studies have demonstrated that cosmic ray exposure (CRE) dating of deformed or displaced geomorphic features allow quantifying long-term rates of deformation in different tectonic and climatic settings [2-4]. However, in western European countries, the erosion rates induced by unfavourable climatic conditions, reinforced by human activities on landscape may limit the accuracy of surface CRE ages. The methodology described hereafter proposes to estimate both the erosion rates and the exposure ages of alluvial surfaces through modelling of the measured decrease with depth of in situ-produced ${ }^{10} \mathrm{Be}$ concentrations, using a Khi-square inversion method.

\section{Structural and seismological background: the Provence area}

The Provence region is located in south-eastern France at the transition between the Pyrenean and the Alpine mountain belts. The Provence structural pattern results from two superimposed collisional periods: Late Cretaceous to Eocene for the Pyrenean chain, and Miocene to Present for the Alps [5-8]. From a structural point of view, the Provence domain is bounded by the Nîmes fault to the west and by the external alpine thrusts to the east (Fig. 1). It is affected by numerous east-west trending thrusts that have either northward (Sainte-Victoire, Sainte-Beaume, Etoile, Ventoux-Lure) or southward (Alpilles, Lubéron, Costes-Trévaresse) vergencies, as well as by regional NE- to NNE-trending oblique strikeslip faults (e.g.; Nîmes, Moyenne Durance, Salon-Cavaillon faults). These faults are inherited from the Variscan and Meso-Cenozoic histories of the region [5-8]. In Provence, the north-verging thrusts are mainly of Pyrenean age, whereas the south-verging thrusts may either correspond to Miocene reactivated Pyrenean structures or pristine Alpine thrusts. These two shortening periods are separated by an Oligocene E-W or NW-SE trending extensional period, which is responsible for normal movement onto the Nîmes and Moyenne Durance faults [5-8]. During the upper Miocene, alpine

*Corresponding author, Tel: +33-1-69156754; E-mail address: siame@geol.u-psud.fr 
thrusts propagated outward, and the vertical movement on the Moyenne Durance Fault (MDF) was inverted (>200m) without, however, cancelling the $\sim 3000 \mathrm{~m}$ Oligocene down-throw. Oligo-Miocene and older strata have been folded by E-W to NE-SW trending folds on the NW up-thrown block while the MDF was inverted first as a pure reverse fault $\left(\mathrm{N} 100^{\circ} \mathrm{E}\right.$-striking compression) then as a reverse fault with a left-lateral horizontal component $\left(\mathrm{N} 160^{\circ} \mathrm{E}\right.$-striking compression) [7]. Since its inversion, the MDF constitutes the western border of the Valensole basin, an Alpine foreland basin filled by the upper Miocene and Pliocene Valensole conglomerates.

The Provence domain is also characterised by tectonic and geomorphic evidences for localised active deformation along individual fault zones $[5,9,10]$. The $60 \mathrm{~km}$-long MDF is probably one of the major active faults in this region. It is the only fault in this region for which present-day activity is demonstrated through both instrumental [11] and historical seismicity [12] (Fig. 1), as well as paleoseismological evidence [13]. From an instrumental point of view, the level of seismicity is low, even though a local seismic network showed that this low seismic activity is characterised by epicentres aligned along the MDF direction [11]. Using inversion of earthquake focal mechanism solutions, Baroux et al. [14] have shown that the present-day state of stress around the MDF is a reverse faulting one $\left(\sigma_{3}\right.$ vertical) with horizontal $\sigma_{1}$ trending $\mathrm{N} 158^{\circ} \mathrm{E}$, implying active reverse oblique slip on the MDF. These results are in good agreement with geodetic results implying that the presentday total left-lateral strike-slip rates on both the MDF and the Nîmes fault are unlikely to exceed 2 $\mathrm{mm} / \mathrm{yr}[15,16]$.

\section{Methodology}

\subsection{Cosmogenic production near the Earth's surface}

The theory and application of terrestrial in situ cosmogenic nuclides have been extensively described in a review paper by Gosse and Phillips [17]. Hereafter, we briefly present the different processes and mechanisms responsible for in situ production of ${ }^{10} \mathrm{Be}$ in rocks. At the Earth's surface, cosmogenic nuclides are produced within mineral lattices through nuclear reactions driven by high energy particles cascading through the atmosphere. Thus, cosmogenic production rates depend on energy dependent cross-section for reactions with the target atoms and on cosmic ray flux entering the Earth's environment. This latter parameter is influenced by the solar activity [18, 19], but depends mainly on the strength of the Earth's magnetic field $[19,20]$. This effect, together with dissipation of cosmic ray particles' energy and flux in the atmosphere, accounts for the observed altitudinal and latitudinal variability in production rates. During the last decade, these altitudinal and latitudinal variations have been modelled using empirical polynomials [21-23]. In this study, Stone's [23] polynomials have been preferred since (1) they allow to take into account the physical properties of cosmic particles propagation in the atmosphere, using the atmospheric pressure as a function of 
altitude, and (2) they better account for the muonic component of the total cosmogenic production (see below).

At the surface, and in the upper few meters of rock below it, production of in situ ${ }^{10} \mathrm{Be}$ is mainly due to three reaction mechanisms: (1) energetic nuclear reactions involving the nucleogenic component of secondary cosmic rays, (2) negative muon capture by the target nucleus, and (3) nuclear reactions of fast muons [17]. The high energy nucleons involved in spallation reactions on silicium and oxygen nucleus to produce in situ ${ }^{10} \mathrm{Be}$ are mostly composed of secondary neutrons with energy in the $\mathrm{MeV}-\mathrm{GeV}$ range. Negative and fast muons are short-lived energetic lepton particles resulting from the decay of high energy pions and kaons produced in the upper part of the Earth's atmosphere. Muons have no strong interaction property and undergo the same type of interactions than electrons. In spite of their very short half-lives at rest $\left(\sim 10^{-6} \mathrm{~s}\right)$, they can reach the surface and interact with exposed minerals. Through the upper few meters below the surface, muonic production of ${ }^{10} \mathrm{Be}$ in quartz mineral mainly involve capture of slow negative muons (hereafter referred as stopping muons) by charged nuclei [17], although columbic interactions of fast muons also contribute at greater depths [24].

When compared to high energy nucleons like secondary neutrons, muons are weaker interactive but higher penetrative particles. Indeed, the effective attenuation length of secondary neutrons is roughly an order of magnitude shorter $\left(\Lambda_{\mathrm{ne}}=160 \pm 10 \mathrm{~g} . \mathrm{cm}^{-2}\right)$ relative to that of stopping muons (on the order of $1500 \mathrm{~g} . \mathrm{cm}^{-2}$ ) [24]. Muons have thus the capacity to penetrate more deeply into rocks and the production rate of ${ }^{10} \mathrm{Be}$ vary with depth as the dominant production process progress from nucleon spallation at the surface, to negative muon capture, and fast muon reactions at great depth. This means that whereas neutron-induced production is dominant near the surface [24], below a few meters reactions with muons become dominant $[25,26]$. This opposition between muonic and spallogenic particles is potentially very useful because the sensitivity to erosion rate decreases as the attenuation length for production increases. Used in combination along depth-profiles, muonic and spallogenic contributions offer the potential to determine for rapidly eroding landforms both the exposure age, using the ${ }^{10} \mathrm{Be}$ concentrations measured in samples at depth, and erosion, using the ${ }^{10} \mathrm{Be}$ concentration measured in near surface samples.

\subsection{Khi-square fit modelling of the data}

For a surface undergoing erosion at a rate $\varepsilon\left(\mathrm{g} \cdot \mathrm{cm}^{-2} \cdot \mathrm{yr}^{-1}\right)$ during a time interval $\mathrm{dt}$, the evolution of the ${ }^{10} \mathrm{Be}$ concentration $(\mathrm{C})$ with time $(\mathrm{t})$ and depth $(\mathrm{x})$ is commonly described by:

$$
\frac{d C}{d t}=P_{0} \cdot e^{-\frac{\rho x}{\Lambda}}+\varepsilon \cdot \frac{d C}{d x}-\lambda \cdot C
$$

where $\mathrm{P}_{0}$ is the surface production rate (at./g/yr), $\Lambda$, the attenuation length $\left(\mathrm{g} / \mathrm{cm}^{2}\right)$ of the considered particle, $\lambda$, the ${ }^{10} \mathrm{Be}$ radioactive decay constant $\left(\mathrm{yr}^{-1}\right)$, and $\rho$ the density $\left(\mathrm{g} / \mathrm{cm}^{3}\right)$ of the matter where production occurs, respectively. Considering the three particle categories responsible for in situ 
production of ${ }^{10} \mathrm{Be}$ (neutrons, stopping and fast muons), and assuming constant rates of erosion and production through time, the differential equation 1 may be solved to yield:

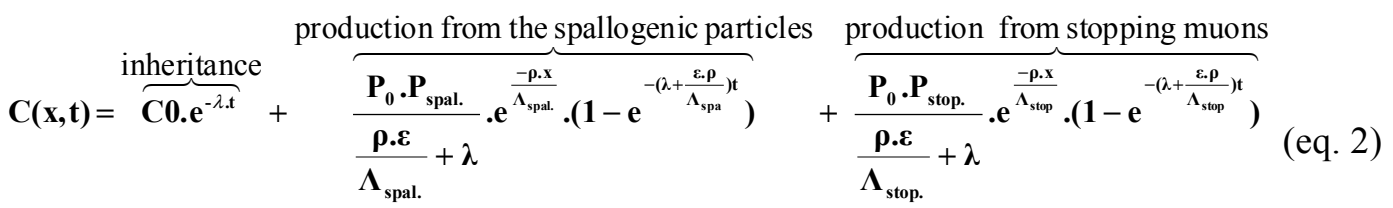

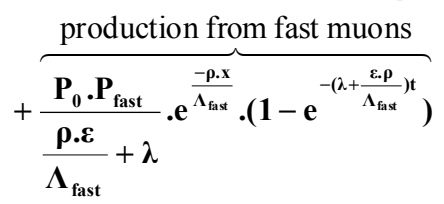

where $\Lambda_{\text {spal. }}, \Lambda_{\text {stop }}$, and $\Lambda_{\text {fast }}$ are the effective attenuation lengths for spallation, negative capture and coulombic interactions, respectively. $\mathrm{P}_{\text {spal., }}, \mathrm{P}_{\text {stop. }}$, and $\mathrm{P}_{\text {fast }}$ are the relative contributions of highly interactive nucleons, negative and fast muons to the total production rate $\left(\mathrm{P}_{\text {spal. }}+\mathrm{P}_{\text {stop. }}+\mathrm{P}_{\text {fast }}=1\right)$, and $\mathrm{C}(\mathrm{x}, 0)$ the number of atoms present at the initiation of the exposure scenario. Since the last ten years, special efforts were conducted to better constrain the muonic contribution to cosmogenic nuclide production at depth [24-29]. Most of these works are based on nuclear physics experiments or numerical models. In this study, we used the reappraisal of the fast muon attenuation length proposed by Braucher et al. [29] which is based on natural samples from a sub-vertical Brazilian lateritic quartz vein: $\Lambda_{\text {spal. }}=150 \mathrm{~g} / \mathrm{cm}^{2}, \Lambda_{\text {stop. }}=1500 \mathrm{~g} / \mathrm{cm}^{2}$, and $\Lambda_{\text {fast }}=5300 \mathrm{~g} / \mathrm{cm}^{2}$, with $\mathrm{P}_{\text {spal }}=97.85 \%, \mathrm{P}_{\text {stop }}=1.5 \%$, and $\mathrm{P}_{\text {fast }}=0.65 \%$. This relative muonic contribution of $\sim 2.15 \%$ to the total ${ }^{10} \mathrm{Be}$ production rate at the surface is in close agreement with recent experimental measurements [27, 28].

Equation 2 allows computing and modelling of the ${ }^{10} \mathrm{Be}$ concentration evolution with time and depth for any alluvial landform that has undergone a single cosmogenic exposure episode. The methodology of sampling vertical profiles was first specifically developed to take into account the potential problem of inheritance [30, 31], which can be significant in alluvial deposits [32, 33]. Because the profile technique is time- and money-consuming, depth profiles generally comprised a limited number of samples. Nevertheless, given a restricted set of ${ }^{10} \mathrm{Be}$ concentrations measured along a depth profile, modelling can be used as a constrained interpolation where few data points can be extended into a continuous function. In this study, we first propose a data modelling using equation 2 and a khi-square $\left(\chi^{2}\right)$ fit based inversion method.

This inversion method assumes that $\mathrm{N}$ data points $\left(\mathrm{C}_{\mathrm{i}}, \mathrm{x}_{\mathrm{i}},\right)[\mathrm{i}=1, \ldots, \mathrm{N}]$, where $\mathrm{C}$ and $\mathrm{x}$ are the ${ }^{10} \mathrm{Be}$ concentration and sampling depth, respectively, can be fitted to a model with $\mathrm{M}$ adjustable parameters. For $\mathrm{N}$ samples located along a depth profile within a well-identified alluvial terrace; i.e., related to the same geomorphic event, a system of $\mathrm{N}$ equations is thus available to solve the unknowns of equation 2 . Inheritance in alluvial deposits being not a priori constant along depth, one will have $\mathrm{N}$ unknowns related to the inheritance carried by each sample in the data set. Thus, using a single nuclide such as ${ }^{10} \mathrm{Be}, \mathrm{N}+2$ parameters should be needed to model erosion, exposure time, and inheritance at the same time. As a first step, we choose to model only erosion and exposure time for alluvial landforms where 
inheritance could be neglected (see hereafter within the application section). During modelling, soil density was allowed to vary between 1.8 and $2.2 \mathrm{~g} / \mathrm{cm}^{3}$ as the downward porosity of the fluvial material is relatively variable within the studied alluvial landforms.

From a theoretical point of view, for any depth profile corresponding to a single exposure history at a constant erosion rate, one can minimise the difference between the measured concentration and the ${ }^{10} \mathrm{Be}$ concentration computed using equation 2. At a specific depth and for one sample, an infinite number of $(t, \varepsilon)$ solutions can be computed to explain the measured ${ }^{10} \mathrm{Be}$ concentration (Fig. 2). In contrast, for a set of samples from a depth profile, there is theoretically only one solution that fits the data set. Because of uncertainties in the concentration measurements, the best fit corresponds to a range of exposure duration and erosion rates. These $(\varepsilon, t)$ solutions define pathways in the mathematical Time-Erosion space, and because each data point $\left(\mathrm{C}_{\mathrm{i},} \mathrm{x}_{\mathrm{i}}\right)$ has its own standard deviation, $\sigma_{\mathrm{i}}$, the maximum likelihood estimate of the model parameters can be obtained by minimising the $\chi^{2}$ quantity:

$$
\chi^{2} \equiv \sum_{i=1}^{N}\left(\frac{C_{i}-C\left(x_{i}, \varepsilon, t\right)}{\sigma_{i}}\right)^{2}
$$

where $\mathrm{C}_{\mathrm{i}}$ is the measured ${ }^{10} \mathrm{Be}$ concentration at the depth $\mathrm{x}_{\mathrm{i}}$, and $\mathrm{C}\left(\mathrm{x}_{\mathrm{i}}, \varepsilon, \mathrm{t}\right)$ is the computed ${ }^{10} \mathrm{Be}$ concentration using equation 2 with a given $(\varepsilon, t)$ solution.

Because data are subject to measurement errors, and landforms to post-depositional processes (bio-, cryoturbation, compaction...), they never exactly fit with the model. To assess whether or not the model is appropriate to explain the dataset, testing the "goodness-of-fit" against some statistical standard is thus needed. If the measurement errors are normally-distributed over the $\mathrm{N}$ data points, it can be demonstrated that the $\chi^{2}$-distribution is given by the following probability distribution (Quality factor, Qf) [34]:

$$
Q f(a, x) \equiv 1-P(a ; x) \equiv \frac{\Gamma(a, x)}{\Gamma(a)} \equiv \frac{1}{\Gamma(a)} \int_{0}^{\infty} \exp (-t) \cdot t^{a-1} . d t \text { with }(\mathrm{a}>0)
$$

where $a=\frac{v}{2}$, with $v$ the model degree of freedom (number of data minus number of modelled parameters), and $x=\frac{\chi^{2}}{2} . \mathrm{P}$ is the probability that the computed $\chi^{2}$ value of a supposed-true model is inferior to a given $\chi^{2}$ value. This monotonic function has the limiting values $P(\mathrm{v}, 0)=0$ and $P(\mathrm{v}, \infty)=1$, and thus rises from near-zero to near-unity values. For some particular data set, computing the Qfprobability of a minimised $\chi^{2}$-quantity $\left(\chi_{\min }{ }^{2}\right)$ provides a quantitative estimation for the model's "goodness-of-fit". The closer Qf is to 1, the less unlikely one is to find a better estimation of the model parameters. In other words, the Qf-probability is a quantitative estimation of whether or not the data fit with the underlying model: a single continuous erosion rate and associated exposure age. For the 
observed data set, the computed $\chi_{\min }{ }^{2}$ value is a minimum for a given $(\varepsilon, t)$ solution. The region within which the computed $\chi_{\min }{ }^{2}$ value increases by no more than a set amount $\Delta \chi^{2}$ defines some confidence region around the modelled $(\varepsilon, t)$ solution. Hereafter, contours of constant $\Delta \chi^{2}$ will define the boundary of our confidence region for the modelled parameters (Fig. 2). Even for a theoretical case study, the geometry of the computed $\chi^{2}$ values in the $(\varepsilon, \mathrm{t})$ space implies that for such parameter modelling, one can not pretend a better solution to $1 \sigma$ confidence level (i.e., $68.3 \%$ ).

\section{Application to natural depth profiles}

\subsection{Sampling site selection}

Studied sites are localised SE France, along the Rhône (site \#1) and the Moyenne Durance (site \#2) rivers (Fig. 1). Sampling site selection was carefully conducted to overcome inheritance and exposure history problems. It is based on absence of soil features such as buried soils, on evidence against terrace disturbance (i.e., preserved original fluvial bedding or imbrications), and the possibility to sample vertical profiles. In this latter case, locations where the exposure time of the vertical side walls was negligible compared to that of the terraces were selected (i.e., outcrops of anthropomorphic origin such as road-cuts or old quarries).

\subsection{Application to a "Villafranchian" Rhône terrace: the Bois Clary alluvial terrace}

\section{a. Structural and geomorphic frameworks}

The Bois Clary terrace (Site \#1, Fig. 1) is located close to the Nîmes fault, near Tavel village, in the eastern part of the Pyrenean-Provençal range (Fig. 3). This region was structured by Upper Eocene thin-skinned tectonics and then peneplanated [8]. During the Oligocene extensional period, regional normal faulting occurs in association with the opening of the western Mediterranean Sea (e.g., the Nîmes fault and its associated antithetic Pujaut fault). The fault escarpments were mainly revealed by differential erosion after planation in relation with the vertical erosion due to the Messinian regression [8].

In this context, the Bois Clary terrace is located within the palaeo-Rhône river valley that was flowing southward to the Mediterranean Sea, west of its present-day valley; i.e., west of the Pujaut basin (Fig. 3). The palaeo-Rhône river valley was progressively filled by Pliocene sands and gravels during the post-Messinian transgression. This conglomeratic aggradational episode ended by the Lower Pleistocene and is termed "Villafranchian" on French geological maps [35]. The Bois Clary terrace is now located at a mean elevation of $130 \mathrm{~m}$, that is roughly $110 \mathrm{~m}$ above the present-day Rhône river bed (Fig. 3). On a topographical basis, the Villafranchian Rhône terraces can be correlated to loess deposits that are located farther north-east at Saint Vallier (Drôme, France). These loess deposits being dated at about $2 \mathrm{Myr}$ on the basis of a tephra horizon [36], as well as sedimentary analysis [37], they provide an interesting time constraint suggesting that the Bois Clary terrace should be close to the steady-state equilibrium for in situ produced ${ }^{10} \mathrm{Be}$. The Bois Clary terrace is thus a good candidate to (1) test the application of the khi-square modelling on natural samples that have

*Corresponding author, Tel: +33-1-69156754; E-mail address: siame@geol.u-psud.fr 
experienced long-term exposure duration, and (2) estimate a regional erosion rate integrated over the Quaternary for such alluvial material.

Since its Lower Pleistocene abandonment, the Bois Clary terrace has evolved throughout the Quaternary, during which climatic conditions have oscillated severely between periglacial and Mediterranean climates. The samples collected with depth within the first two meters of a road-cut below the surface of the Bois Clary alluvial terrace are located far from the natural edge of the terrace. These uppermost meters are characterised by quartzite pebbles and cobbles supported by a reddish silty and sandy matrix composed of clay minerals and detrital quartz grains (Fig. 3). The Bois Clary terrace soil most probably evolved by geomorphic processes such as rapid deflation controlled by complete dissolution of the carbonate fraction initially included in the alluvial deposit, depletion in the upper soil horizons by weathering and disintegration of the crystalline clasts, and illuviation and compaction of the silty matrix. These surface processes can be responsible for dramatic losses of matter [38], and the quartzite cobbles that are currently exposed at and near the surface were initially located at greater depths. These quartzite cobbles were thus brought to the surface by geomorphic processes undergoing a similar cosmogenic nuclide exposure scenario.

\section{b. Khi-square $\left(\chi^{2}\right)$ fit based inversion modelling for the "Villafranchian" Bois Clary terrace}

Samples from the surface (VL97-7), and from a depth profile (CVL97-14: $0 \mathrm{~cm}$, CVL97-11: 45 cm; CVL97-8: $95 \mathrm{~cm}$; CVL97-5: $145 \mathrm{~cm}$ ) have been processed to model the exposure history of the Bois Clary terrace (Table 1). The ${ }^{10} \mathrm{Be}$ concentrations measured along the depth profile show an exponential decrease with depth suggesting that no vertical mixing has occurred during soil evolution and compaction (Fig. 3). Moreover, this exponential decrease with depth also suggests that the studied terrace deposits have remained exposed unshielded from cosmic radiations.

The model computed using the ${ }^{10} \mathrm{Be}$ concentrations measured along depth suggests that the Bois Clary terrace fill has experienced at least 1.2 Myr of cosmic ray exposure with an integrated erosion rate of $24 \mathrm{~m} / \mathrm{Myr}$. This solution is obtained for a $\chi_{\min }{ }^{2}$ value that provides a Qf value of 0.72 for a degree of freedom of 2, signifying that the overall dataset is in close agreement with a single and continuous erosion rate and associated exposure age. This solution is also in close agreement with the Saint-Vallier "Villafranchian" loess deposits dated at 2 Myr [36, 37]. In contrast with the theoretical case study presented (Fig. 2), the model plot shows that the calculated $\chi^{2}$-values define a relatively elongated flat "topographic valley" parallel to the exposure time axis (Fig. 4). This pattern should be interpreted as a visualisation of the so-called steady-state equilibrium for in situ production of ${ }^{10} \mathrm{Be}$, at which the measured ${ }^{10} \mathrm{Be}$ concentrations can only be related to a maximum erosion rate. Although the model tested has less depth-curvature than the data seem to require, this modelled erosion rate is in relatively good agreement with the $20 \pm 4 \mathrm{~m} / \mathrm{Myr}$ erosion rates deduced from the ${ }^{10} \mathrm{Be}$ concentration measured in the surface samples (VL-97.7 and CVL97-14, Table 1), assuming that the Bois Clary terrace is at the steady-state equilibrium.

*Corresponding author, Tel: +33-1-69156754; E-mail address: siame@geol.u-psud.fr 


\section{c. Significance of the estimated $\sim 24 \mathrm{~m} / \mathrm{Myr}$ erosion rate}

Under some geological circumstances, assessing the cosmogenic content within detrital minerals has already been used to determine the mean erosion rate across a catchment [32, 39]. This approach has been used to estimate large scale erosion rates ranging from 20 to $100 \mathrm{~m} / \mathrm{Myr}$ from the study of western European rivers [33]. The erosion rate derived from the data modelling of the Bois Clary terrace has a different significance as it does not correspond to an erosion rate integrated over a specific drainage basin but to a surface lowering due to combined climatically-driven processes, which are described above, and erosion driven by regional uplift, illustrated by an altitude difference of roughly $110 \mathrm{~m}$ between the Bois Clary terrace and the present-day Rhône river bed. Although the $\sim 24$ $\mathrm{m} / \mathrm{Myr}$ erosion rate modelled in this study may appear high, it is consistent with the results of previous studies on geomorphic processes responsible for soil development and compaction on Quaternary alluvial materials within nearby valleys. From sedimentary analyses, Bornand [38] reconstructed a surface lowering ranging between 55 and $100 \mathrm{~m}$ for Villafranchian terraces in the middle Rhône valley, which yields erosion rates ranging between 27 and $50 \mathrm{~m} / \mathrm{Myr}$ on the basis of the Saint-Vallier loess deposits age. More recently, in their study located in the French Western Alps, Brocart et al. [40] estimated an erosion rate of $30 \pm 10 \mathrm{~m} / \mathrm{Myr}$ from ${ }^{10} \mathrm{Be}$ concentrations measured within samples scattered on top of the old surface of a series of alluvial terraces.

\subsection{Application to Moyenne Durance alluvial terraces}

\section{a. Structural framework}

As already described, the MDF is probably one of the most active faults in Provence (Fig. 1). In the Manosque region, the MDF is organised in parallel fault strands localised in the south-eastern flank of the Manosque anticline (Fig. 5) [7]. The morphology associated with the eastern flank of the Manosque anticline is mainly characterised by a series of aligned flatirons carved into strongly ( 90 to $50^{\circ} \mathrm{SE}$ ) tilted Upper Miocene Pliocene deposits (marine sands and Valensole I fluvial conglomerates) which delineates a discontinuous topographic depression incised within the Serravalian-Tortonian molasses that rest on the Burdigalian limestone (Fig. 5 and 6). Within this geomorphic framework, the MDF strands can either be located within the topographic depression carved into the Tortonian molasses or to the east of the flatirons; that is beneath the Durance river alluvium. An evaluation of Recent movement on these fault strands is, however quite difficult. Despite an important effort to localise surface fault traces [7,9], evidence for them is tenuous as, in the Durance alluvial plain, the topography is chiefly controlled by erosional contacts between the alluvial terraces or by human activities. In the topographic depression carved into the Tortonian molasses, differential erosion is self-sufficient to explain the observed morphology by itself. To date, the Valveranne paleoseismological evidence, located in the topographic depression carved within the Tortonian molasses (Fig. 7), is the only observation site in this area where recent activity has been demonstrated [12]. Here, a paleoseismologic trench showed that strata dated at $26800 \pm 6100$ years are deformed by a

*Corresponding author, Tel: +33-1-69156754; E-mail address: siame@geol.u-psud.fr 
west-vergent kink-fold. This deformation is unconformably covered by a $9123 \pm 190$ years old colluvium [12]. The corresponding displacement being on the order of $1.2 \mathrm{~m}$, the observations suggest that this deformation occurred during a seismic event of relatively high magnitude $(6.4<\mathrm{Mw}<6.9)$ some 10 to $26 \mathrm{kyr}$ ago [7]. Unfortunately, the Valveranne inferred west-verging and east-dipping fault associated with the Valveranne kink-fold is most probably associated with an antithetic secondary fault and cannot be regarded as a major surface expression of the MDF (Fig. 6).

\section{b. Geomorphic framework}

To assess whether or not some active tectonic process is occurring within the Moyenne Durance plain, we present hereafter some geomorphic lines of evidence. As a first step, one can consider the basis of the early Quaternary Valensole II conglomerates that constitutes the top of the Valensole plateau on the eastern side of Durance River (Fig. 5 and Fig. 6). These alluvial conglomerates correspond to the late aggradational episode filling of the Messinian palaeovalleys that ended by the lowermost Pleistocene (i.e., $\sim 2$ Myr ago) [41]. On the eastern side of the Durance River, the basis of Valensole II conglomerates is located at an elevation of $500 \mathrm{~m}$; that is $\sim 170 \mathrm{~m}$ above the present-day Durance river bed, yielding a mean incision rate of $\sim 0.08 \mathrm{~mm} / \mathrm{yr}$ during the last $\sim 2 \mathrm{Myr}$. This incision rate gives an estimation of the regional incision rate driven by both climatic processes and regional uplift. On the western side of the Durance River, the Valensole II conglomerates are preserved at a higher elevation on top of a topographical relict (Le Pigeonnier, $572 \mathrm{~m}$ ) in faulted contact with the eastern core of the Manosque anticline (Fig. 6). At Le Pigeonnier, the basis of the Valensole II conglomerates is located at an elevation of $540 \mathrm{~m}$ (Fig. 6). This observation suggests that the basis of the Valensole II conglomerates has experienced differential $\sim 40 \mathrm{~m}$ uplift during the last $\sim 2 \mathrm{Myr}$, yielding a mean $0.02 \mathrm{~mm} / \mathrm{yr}$ uplift rate of the south-eastern flank of the Manosque anticline respect to the Valensole plateau. Interestingly, when compared to the present-day Largue river bed (Fig. 5), which has an elevation of $335 \mathrm{~m}$ where it enters into the Durance alluvial, the incision rate calculated from the basis of the Valensole II conglomerates, is on the order of $0.1 \mathrm{~mm} / \mathrm{yr}$, corresponding to the sum of the previously estimated regional incision and lower bound for the Manosque anticline uplift.

A second line of evidence is provided by the alluvial terraces located along the Durance River. In the Manosque region, a careful examination allows to recognise at least three generations of alluvial terraces on the basis of their respective topographical positions. These alluvial terraces are mapped on the figure 5, localised on the schematic geological cross-sections presented on the figure 6 , and informally termed low, intermediate, and high terraces, respectively. Because this set of alluvial terraces lacks of precise chronological constraints, it is relatively difficult to correlate the high and intermediate terraces located on both sides of the Durance River. In the Manosque area, most of the secondary rivers that drain out from the Manosque anticline into the Durance alluvial plain are currently incising bedrock, and the high and intermediate terraces developed as strath terraces, generally onto the Upper Miocene Valensole I conglomerates. As an example, the high (Fx) and intermediate (Fy) alluvial terraces are located respectively some $40 \mathrm{~m}$ and $10 \mathrm{~m}$ vertically above the

*Corresponding author, Tel: +33-1-69156754; E-mail address: siame@geol.u-psud.fr 
present-day Largue river bed where this river enters into the Durance alluvial plain (Fig. 5 and Fig. 6). This observation agrees with active uplift related to the growth of the Manosque anticline.

Industrial seismic lines provide evidence for a major west-dipping fault segment at depth but they do not permit to clearly evaluate if the MDF is propagating up to the surface [42]. Nevertheless, in case of surface propagation, these fault segments should reach the Moyenne Durance alluvial plain. The intersection between the fault imaged at depth and the topographic surface corresponds to a SEfacing terrace riser located between the lower $(\mathrm{Fz})$ and intermediate $(\mathrm{Fy})$ Quaternary alluvial terraces (Fig. 5). This terrace riser has been previously interpreted as resulting from a tectonic control [41], and may be considered as an escarpment partly formed by the MDF motion. However, significant anthropomorphic and erosional contributions for this escarpment morphogenesis have also been observed. Inspection of the drainage network composed of the secondary rivers that drain out of the Manosque anticline into the Durance alluvial plain shows that the inflection points (i.e., the point where the river profiles acquire their downstream flat topography compare to their high angle upstream slope) of the river topographic profiles are also well-aligned with the SE-looking topographic escarpment (Fig. 5). Interestingly, farther south, where the MDF segment is entering the bedrock, these inflection points are no more located at the transition between two terraces, but within the low alluvial terrace (Fig. 5), suggesting some tectonic control of the shape of the river topographic profiles along the SE-facing topographic escarpment.

\section{c. Near surface geophysical survey of the MDF}

To image near surface fault propagation, a shallow seismic reflection survey was conducted in this area [7]. The high resolution seismic profiles acquired in the Manosque area image very poorly the upper $100 \mathrm{~m}$ of the subsurface; however, first arrivals from all these shots, as well as additional inverse shots, were used to produce a reliable refraction profile (Fig. 7). The upper layer has a velocity of $600 \mathrm{~m} / \mathrm{s}$ (weathered layer?) while the substratum, interpreted as Valensole I conglomerates, has a much higher velocity close to $3000 \mathrm{~m} / \mathrm{s}$. Coincident ground penetrating radar profiles (GPR) were acquired to resolve the uppermost meters below the surface. Although penetration was poor due to conductive near surface layers, the $50 \mathrm{MHz}$ profile shown in Figure 9 suggests deformation within the underneath alluvial deposits.

The $250 \mathrm{~m}$-long shallow seismic profile (interpreted in Fig. 7) allows to identify a clear velocity contrast interface some 10-15 m below the topographic surface. This seismic interface has been interpreted as the Weathering Zone Limit (WZL) that marks the transition between the unconsolidated Quaternary alluvial conglomerates and the consolidated Valensole conglomerates. This interpretation agrees with a piezoelectric study conducted by the French Agency for Electricity (EDF) during building of the Durance river hydroelectric facility [7]. The WZL shows across strike depth variations as it is located at $\sim 11 \mathrm{~m}$ below the surface of the upper alluvial terrace whereas it is $\sim 14 \mathrm{~m}$ deep below the surface of the lower alluvial terrace. In addition, this abrupt change in the WZL depth is localised vertically below the SE-facing topographic escarpment (Fig. 5). These observations agree with the fact

*Corresponding author, Tel: +33-1-69156754; E-mail address: siame@geol.u-psud.fr 
that the lower terrace $(\mathrm{Fz})$ is inset into the alluvial deposits of the upper terrace (Fy), and, in first order, this geometry is more likely controlled by fluvial processes; i.e., alternating aggradational episodes of alluvium along the Durance river's course followed by down cutting, which leaves the former alluvial surface abandoned. Nevertheless, the shallow seismic profile supports a clear difference in thickness between the two alluvial terraces: the Fy and Fz thickness being on the order of 11 and $14 \mathrm{~m}$, respectively.

\section{d. Sampling of the alluvial terraces and $\chi^{2}$-modelling}

To better constrain the landscape evolution experienced by the upper alluvial terrace (Fy), a depth profile was sampled in an abandoned quarry (Fig. 7), where the fluvial bedding could be ascertained. The upper alluvial terrace is made of an unconsolidated conglomerate characterised by heterometric and heterogenic cobbles and pebbles supported by a silty, detrital and quartz-grained matrix. Vertical sampling was combined with surface sampling to check the effect of climatic and human factors on surface samples. No vertical outcrop suitable for the profiling technique was available for the lower terrace; it was therefore replaced by a classical surface sampling of large quartzite cobbles (Table 1).

The ${ }^{10} \mathrm{Be}$ concentrations measured in the surface cobbles sampled onto the lower and on the upper alluvial terraces exhibit a large scattering, ${ }^{10} \mathrm{Be}$ concentrations of the $\mathrm{Fz}$ surface samples ranging between 13000 and 42000 at./g. These surface concentrations yield young minimum exposure ages, ranging between $2.0 \pm 0.6$ and $6.4 \pm 1.9 \mathrm{kyr}$ (Table 1). For the upper surface, the scattering of the surface sample ${ }^{10} \mathrm{Be}$ concentrations is even more important (Table 1), and clearly illustrates the need to apply the depth-profile technique in heavily-human modified areas. If the scatter in ${ }^{10} \mathrm{Be}$ concentration on the Fz surface can probably be explained by a combined action of soil development and agricultural perturbation, it is most likely the effect of human action on landscape that has caused the scattering evidenced on the Fy alluvial surface. Thus, taking into account this large scatter of the ${ }^{10} \mathrm{Be}$ concentrations on top of the Fy alluvial terrace, the khi-square method has been applied only to samples located at depth along the profile. The ${ }^{10} \mathrm{Be}$ concentrations measured within the four samples of the profile through the upper alluvial terrace show a clear exponential decrease with depth, suggesting that no vertical mixing occurred below $70 \mathrm{~cm}$ depth during soil evolution and compaction. Moreover, the $3 \mathrm{~m}$-deep sample (PCAR97-0) exhibits a very low ${ }^{10} \mathrm{Be}$ concentration, suggesting a negligible geological inheritance for this alluvial material.

The $\chi^{2}$-modelling of the profile sampled along depth within the upper three meters of the Fy alluvial terrace suggests that this landform has experienced cosmic ray exposure during $70 \mathrm{kyr}$ with an integrated erosion rate of roughly $62 \mathrm{~m} / \mathrm{Myr}$ (Fig.8). In contrast with the $\chi^{2}$-modelling of the Bois Clary alluvial terrace, the model plot shows that the calculated $\chi^{2}$-values define a pattern similar to that obtained for the theoretical case study (Fig. 8), indicating that the Fy Manosque terrace has not reached the steady-state equilibrium.

e. Significance of the estimated parameters

*Corresponding author, Tel: +33-1-69156754; E-mail address: siame@geol.u-psud.fr 
The result of the $\chi^{2}$-modelling is characterised by a relatively high quality factor $(0.92)$ which means that the measured ${ }^{10} \mathrm{Be}$ concentration distribution along depth is well-explained by a single and continuous erosion rate and associated exposure age. Within their confidence limits, the parameters modelled for the profile sampled on the upper three meters of the Manosque Fy terrace suggest that the abandonment of this alluvial terrace should have occurred between 30 and $140 \mathrm{kyr}$; i.e., during the early Late Glacial or end of Penultimate glacial periods. The modelled erosion rate is ranging between roughly 40 and $84 \mathrm{~m} / \mathrm{Myr}$. Integrated over time span corresponding to the Manosque terrace modelled ages, these erosion rates imply that the terrace suffered a surface lowering ranging between 2.7 and 5.4 meters. Interestingly, these values are on the order of the $3 \mathrm{~m}$ difference of thickness observed between the Fy and Fz terraces along the 250 m-long shallow seismic profile (Fig. 7).

\section{Discussion}

Alluvial terraces are inherently transient and instable elements in the landscape, their erosion depends on a lot of different factors such as surface slope, local geomorphic and climatic setting, and the nature of the terrace material. In this study, erosion rates integrated over a time-span of several tens of thousand to a couple of million years have been estimated. One of the striking results is that, the best-fit erosion rate modelled for the Manosque terrace is roughly three times greater than the bestfit erosion rate modelled for the Bois Clary terrace (62 versus $24 \mathrm{~m} / \mathrm{Myr}$ ). Nevertheless, a strong difference in climate cannot be put forward as both studied terraces are located within the same Mediterranean climatic setting. Unfortunately, the high erosion rate could not be confirmed at Manosque on older deposits due to the lack of suitable sampling sites within the Valensole II conglomerates which should be at the steady-state equilibrium respect to the in situ production of ${ }^{10} \mathrm{Be}$. In their study along the Büech river (French Western Alps), located in a somewhat more Alpine climatic setting, Brocart et al. [40] proposed a 30 $\pm 10 \mathrm{~m} / \mathrm{Myr}$ estimate of erosion rate on terraces from

${ }^{10} \mathrm{Be}$ concentrations measured within samples scattered on top of $\sim 190 \mathrm{kyr}$ old alluvial terraces. All these erosion rate estimates corresponding to surface lowering, it is interesting to compare them with the incision rates in the same areas. The Büech river terraces record a mean long-term fluvial incision rate of $\sim 0.8 \mathrm{~mm} / \mathrm{yr}$ over the last $190 \mathrm{kyr}$, similar to long-term denudation of the External Crystalline Massifs [40]. In the Rhône region, the Bois Clary terrace is located roughly $110 \mathrm{~m}$ above the presentday Rhône river bed (Fig. 3), yielding an incision rate of $\sim 0.06 \mathrm{~mm} / \mathrm{yr}$ if one accepts a $\sim 2 \mathrm{Myr}$ age for the Villafranchian Rhône terrace. In the Manosque area, the basis of Valensole II conglomerates located above the right bank of the Durance river bed (Fig. 6), provided a mean incision rate of $\sim 0.1$ $\mathrm{mm} / \mathrm{yr}$ during the last $\sim 2 \mathrm{Myr}$ (see previous section). From this comparison it appears that high surface lowering rates on flat alluvial surfaces are not directly correlated with the highest linear incision rates. Since the highest surface erosion rate is calculated for the Manosque site which is located on the eastern flank of the actively growing Manosque anticline; then the possibility of some tectonic forcing has to be discussed.

*Corresponding author, Tel: +33-1-69156754; E-mail address: siame@geol.u-psud.fr 
The incision of the Largue River within the Manosque anticline has occurred at a mean rate of $\sim 0.1 \mathrm{~mm} / \mathrm{yr}$ during the last $\sim 2 \mathrm{Myr}$. This estimate is a lower bound value since the Early Quaternary Valensole II conglomerates are in faulted contact with the Oligocene core of the anticline (Fig. 8). The erosional basis of the Fy alluvial terrace, located where the Largue valley opens out into the Durance alluvial plain (Fig. 6), has an elevation of $340 \mathrm{~m}$, that is $\sim 7 \mathrm{~m}$ vertically above the present-day Largue river bed (Fig. 6). This topographical position also suggests that, during the last $\sim 70 \mathrm{kyr}$, the incision of the Largue river also occurred at a mean rate of $0.1 \mathrm{~mm} / \mathrm{yr}$. Moreover, a similar incision value would be obtained between the bases of the $\sim 2 \mathrm{Myr}$ old deposits and the one of the $\sim 70 \mathrm{kyr}$ old terrace. The geophysical profile on figure 7 unveils that the basis of the $\mathrm{Fz}$ alluvial terrace is $\sim 6 \mathrm{~m}$ inset into the basis of the Fy terrace. Taking into account that this inset occurred after Fy abandonment ( $70 \mathrm{kyr}$ ago) and before Fz deposition ( $\sim 15 \mathrm{kyr}$ ago correlating Fz to the Last deglaciation), a river incision of $\sim 0.1 \mathrm{~mm} / \mathrm{yr}$ can also be estimated. Since the incision rate of the Largue river into the growing Manosque anticline appears constant at different time-scale of the Quaternary. In this context, the long-term incision rate may be considered in a first order as roughly equivalent to the uplift tectonic rate. As the calculated differential uplift rate of the Manosque anticline is at least of $0.02 \mathrm{~mm} / \mathrm{yr}$ respect to the Valensole plateau (see previous section), this value can be considered as a minimum vertical slip rate value for the southern segment of the MDF.

Concerning the MDF, two hypotheses can thus be formulated: (1) the fault is about to reach the surface and is just hidden by Recent Quaternary deposits, structurally-controlling the geometry of the alluvial terraces; (2) the fault is blind and dies out within the Valensole conglomerates. Whatever the hypothesis, the studied Fy terrace is located on the hangingwall block of the southern MDF segment. Considering hypothesis 1 , the surface fault trace of the southern segment must then be located farther to the south-east, probably at a distance of $\sim 60 \mathrm{~m}$ from the topographic escarpment as suggested by a GPR profile (Fig. 5). In such a case, the $\sim 6 \mathrm{~m}$ vertical offset of the WZL might be partly caused by the ramping off of the MDF southern segment, that may be associated to the $<1 \mathrm{~m}$-high, E-facing warping of the lower alluvial terrace imaged by the topographic survey conducted together with the shallow seismic profile (Fig. 7). From seismic lines, it appears that the geometry of the $\mathrm{N} 37^{\circ} \mathrm{E}$-striking southern strand of the MDF is a $60^{\circ} \mathrm{W}$ dipping reverse fault [42], and according to Baroux [7] this segment has a calculated displacement vector with a rake of $\sim 78^{\circ} \mathrm{N}$ (i.e., small left-lateral strike-slip component). Taking into account the estimated $\sim 0.02 \mathrm{~mm} / \mathrm{yr}$ uplift rate of the south-eastern flank of the Manosque anticline respect to the Valensole plateau, this geometry at depth would yield a slip rate on the fault of $\sim 0.03 \mathrm{~mm} / \mathrm{yr}$, consistent with expected slip rates of individual faults located in $\mathrm{SE}$ France. Since the southern segment is $\sim 25 \mathrm{~km}$-long, the maximum probable magnitude would range from 6.3 to 6.7 with associated average displacements of 0.4-0.7 $\mathrm{m}$ [43]. These fault parameter estimates, as well as the fault slip rate, would imply recurrence intervals ranging from 13000 to 23000 years which are similar to the one estimated by Sébrier et al. [12] at Valveranne paleoseismological site.

*Corresponding author, Tel: +33-1-69156754; E-mail address: siame@geol.u-psud.fr 
Alternatively, the high surface erosion rate at Manosque may not result from tectonic forcing. Indeed, the confidence limit intervals of the modelled parameters also agree with the possibility that the erosion rates between Bois Clary and Manosque may be closer. As a matter of fact, the upper bound value at Bois Clary (27 m/Myr) is the $2 / 3$ of the lower bound value at Manosque ( $40 \mathrm{~m} / \mathrm{Myr}$ ). Even if there is still a significant difference; this one may be explained from the difference in geomorphic setting. In the case of the Bois Clary terrace, the samples were collected from a horizontal terrace surface, far from the natural edges of the terrace. In this context, the modelled erosion rate results most probably from soil development, dissolution of mobile elements, and eolian deflation with a small contribution of slope wash. In contrast, the samples of the Manosque area profile were collected thanks to an abandoned quarry relatively close to the SE-facing terrace riser. Consequently, these differences in setting may appears sufficient to set up mechanical erosion and transport of material by soil creep, and slope wash, and may provide a viable explanation for the differences in erosion rates. Therefore, the higher surface erosion at Manosque may not be indicative of tectonic uplift.

\section{Conclusions}

This paper presents the results of a depth-profiling technique applied to alluvial terraces located along the Rhône and the Moyenne Durance rivers (SE France). The expected decrease with depth of the measured ${ }^{10} \mathrm{Be}$ concentrations has been modelled using a khi-square inversion in order to constrain the exposure history of studied alluvial landforms. The geomorphic processes responsible for the soil evolution of old Quaternary landforms, has been calibrated to be $19-27 \mathrm{~m} / \mathrm{Myr}$ which is in close agreement with other previous studies [38, 40]. Quaternary climate being characterised by severe climatic oscillations between periglacial and Mediterranean climatic zones, this lowering rate may be thus considered as the mean Quaternary value. The Bois Clary Villafranchian terrace appearing to be close to the steady-state equilibrium for in situ production of ${ }^{10} \mathrm{Be}$, the khi-square inversion provides a relatively well-constrained proxy for the surface erosion rate in Provence.

In the Manosque area, the studied terrace appears to be far from this steady-state equilibrium. The erosion rate bracketing estimated by the khi-square inversion is thus less constrained than at Bois Clary. Nevertheless, this inversion method provides a fairly good bracketing of the exposure age; the abandonment of the Fy Manosque terrace occurred between the end of the Penultimate glacial and the early Late Glacial periods. This modelled age allows estimating the incision rate comparing the alluvial terrace elevations with topographic river profiles. Even if a small number of comparison points are available in the studied region, it seems that no simple and direct relationship can be established between surface lowering rates on flat alluvial surfaces and linear incision rates.

In conclusions, the khi-square modelling of erosion rate and associated exposure time using depthprofile technique appears a very promising method for improving exposure scenarios experienced by landforms in regions where the landscape is human-modified. The model presented in this study provides a best-fit for a single continuous erosion rate and associated exposure age with inheritance

*Corresponding author, Tel: +33-1-69156754; E-mail address: siame@geol.u-psud.fr 
that can be neglected but cannot handle more complicated erosion/exposure histories. Further improvements are thus needed to account for more complicated exposure scenarios and to better address the potential problem of inheritance. These improvements will probably require the use of a double nuclide system (e.g., ${ }^{10} \mathrm{Be}$ and $\left.{ }^{26} \mathrm{Al}\right)$.

\section{Acknowledgments}

This study benefited of a co-operative agreement between the IRSN (BERSSIN), OrsayTerre and IN2P3, and of the E.U. project S.A.F.E. (EVG1-2000-22005). ${ }^{10}$ Be analyses were performed at the Tandétron accelerator mass spectrometry facility, Gif-sur-Yvette, France which is supported by CNRS, CEA and IN2P3. Funding for sampling and previous analyses was provided by IRSN with the contribution of the PROSE and PNRN programs (INSU-CNRS). The code for computing "Ki-square fit modelling" has been developed within the framework of the S.A.F.E. project with the helpful assistance of M. Pessel and V. Frey. SPOT images were provided thanks to the ISIS program support (CNES). Special thanks are due to the following persons for their assistance in sampling (F. Ego), sample preparing (C. Bordes), and in AMS measurements (J. Lestringuez). This paper greatly benefited from careful and constructive reviews by P. Davy and an anonymous reviewer.

\section{References}

[1] C. DeMets, R.G. Gordon, D.F. Argus, S. Stein, Current plate motions, Geophys. J. Int. 21 (1994) 2191-2194.

[2] J.F. Ritz, E.T. Brown, D.L. Bourlès, H. Philip, A. Schlupp, G.M. Raisbeck, F. Yiou \& B. Enkhtuvshin, Slip rates along active faults estimated with cosmic-ray-exposure dates: Application to the Bogd fault, Gobi-Altaii, Mongolia, Geology 23 (1995) 1019-1022.

[3] E.T. Brown, D.L. Bourlès, B.C. Burchfield, D. Qidong, L. Jun, P. Molnar, G.M. Raisbeck, F. Yiou, Estimation of slip rates in the Southern Tien Shan using cosmic ray exposure dates of abandoned alluvial fans, Geol. Soc. Am. Bull. 110 (1998) 377-386.

[4] L.L. Siame, O. Bellier, M. Sébrier, D.L. Bourlès, P. Leturmy M. Perez, M. Araujo, Seismic hazard reappraisal from combined structural geology, geomorphology and cosmic ray exposure dating analyses: the Eastern Precordillera thrust system (NW-Argentina), Geophys. J. Int. 149 (2002) 1-20.

[5] P. Combes, La tectonique récente de la Provence occidentales : microtectonique, caractéristiques dynamiques et cinématiques, Méthodologie de la zonation tectonique en relation avec la sismicité, unpublished $\mathrm{PhD}$ Thesis, Université Louis Pasteur, Strasbourg, France (1984), 182 pp.

[6] C. Champion, Déformation de la Provence occidentale depuis le Miocène: étude structurale, utilisation des surfaces géomorphologiques marqueurs et analyse quantitative du relief, unpublished PhD Thesis, Université d'Aix-Marseille III, France (1989), 222 pp.

[7] E. Baroux, Tectonique active en région à sismicité modérée : le cas de la Provence (France), Apport d'une approche pluridisciplinaire, unpublished PhD Thesis, Université de Paris-Sud, France (2000), 327 pp.

[8] J.P. Peulvast, E. Baroux, O. Bellier, M. Sébrier, Le problème de l'activité des failles de Nîmes, de SalonCavaillon et de la Moyenne Durance (SE de la France): apports de la géomorphologie structurale, Géomorphologie: Relief, processus, environnement 4 (1999) 327-358.

*Corresponding author, Tel: +33-1-69156754; E-mail address: siame@geol.u-psud.fr 
[9] Ritz, J.F. Tectonique récente et sismotectonique des Alpes du Sud, analyse en termes de contraintes. Quaternaire 3 (1992) 111-124.

[10] B. Grellet, P. Combes, T. Granier, H. Philip, B. Mohammadioun, Sismotectonique de la France métropolitaine dans son cadre géologique et géophysique, avec atlas de 23 cartes au 1/4000000 et une carte au 1/1000000, Mém. Soc. Géol. Fr., 164 (1993), vol. 1 : 76 pp., vol. 2 : 24 pl. et une carte.

[11] P. Volant, C. Berge-Thierry, P. Dervin, M. Cushing, G. Mohammadioun, F. Mathieu, The south eastern Durance fault permanent network: preliminary results, J. Seismol. 4 (2) (2000) 175-189.

[12] M. Sébrier, A. Ghafiri, J.-L. Blès, Paleoseismicity in France: Fault trench studies in regions of moderate seismicity, J. Geodyn. 24 (1997) 207-217.

[13] A. Levret, J.-C. Blake, M. Cushing, Atlas of macroseismic maps for French earthquakes with their principal characteristics, Nat. Haz. 10 (1994) 19-46.

[14] E. Baroux, N. Béthoux, O. Bellier, Analyses of the stress field in the southeastern France from earthquake focal mechanisms, Geophys. J. Int. 145 (2001) 336-348.

[15] G. Ferhat, K. Feigl, J.-F. Ritz, A. Souriau, Geodetic measurement of tectonic deformation in the southern Alps and Provence, France, 1947-1994, Earth Planet. Sci. Lett. 159 (1998) 35-46.

[16] E. Calais, R. Bayer, J. Chéry, F. Cotton, E. Doerflinger, M. Flouzat, F. Jouanne, M. Kasser, M. Laplanche, D. Maillard, Regal : réseau GPS permanent dans les Alpes occidentales. Configuration et premiers résultats: REGAL: a permanent GPS network in the Western Alps. Configuration and first results., Comptes Rendus de l'Académie des Sciences - Series IIA - Earth and Planetary Science (331) Issue 7 (2000) 435-442.

[17] J.C. Gosse, F.M. Phillips, Terrestrial in situ cosmogenic nuclides: Theory and application, Quaternary Science Reviews 20 (2001) 1475-1560.

[18] K. O'Brien, Secular variations in the production of cosmogenic isotopes in the Earth's atmosphere, J. Geophys. Res. 84 (1979) 423-431.

[19] E. Bard, W.S. Broecker, The last deglaciation: absolute and radiocarbon chronologies. Series I: Global Environmental Change, 2 Springer-Verlag Berlin (1992).

[20] C. Robinson, G.M. Raisbeck, F. Yiou, B. Lehman, C. Laj, The relationship between ${ }^{10}$ Be and geomagnetic field strength records in central North Atlantic sediments during the last $80 \mathrm{ka}$, Earth Planet. Sci. Lett. 136 (1995) 551-557.

[21] D. Lal, Cosmic ray labelling of erosion surfaces: in situ nuclide production rates and erosion models, Earth Plan. Sci. Lett. 104 (1991) 424-439.

[22] T.J. Dunai, Scaling factors for production rates of in situ produced cosmogenic nuclides: a critical reevaluation, Earth Planet. Sci. Lett. 176 (1999) 157-169.

[23] J.O. Stone, Air pressure and cosmogenic isotope production, J. Geophys. Res., 105 B10 (2000) 2375323759.

[24] E.T. Brown, D.L. Bourlès, F. Colin, G.M. Raisbeck, F. Yiou, S. Desgarceaux, Evidence for muon-induced production of ${ }^{10} \mathrm{Be}$ in near surface rocks from Congo, Geophys. Res. Lett. 22 (1995a) 703-706.

[25] J.O. Stone, J.M. Evans, L.K. Fifield, G.L. Allan, R.G. Cresswell, Cosmogenic chlorine-36 production in calcite by muons, Geochimica et Cosmochimica Acta 623 (1998) 433-454.

*Corresponding author, Tel: +33-1-69156754; E-mail address: siame@geol.u-psud.fr 
[26] D.E. Granger, A.L. Smith, Dating buried sediments using radioactive decay and muogenic production of ${ }^{26} \mathrm{Al}$ and ${ }^{10} \mathrm{Be}, \mathrm{Nucl}$. Instrum. Methods Rhys. Res. B 172 (2000) 822-826.

[27] B. Heisinger, D. Lal, A.J.T. Jull, P. Kubik, S. Ivy-Ochs, S. Meumaier, K. Knie, V. Lazarev, E. Nolte, Production of selected cosmogenic radionuclides by muons, 1. Fast muons, Earth and Planetary Science Letters 6233 (2002) 1-11.

[28] B. Heisinger, D. Lal, A.J.T. Jull, P. Kubik, S. Ivy-Ochs, K. Knie, E. Nolte, Production of selected cosmogenic radionuclides by muons, 2. Capture of negative muons, Earth and Planetary Science Letters 6234 (2002) 1-13.

[29] R. Braucher, D.L. Bourlès, E.T. Brown, F. Colin, Re-evaluation of ${ }^{10}$ Be production by muons, Earth and Planetary Science Letters 211/3-4 (2003) 251-258.

[30] R.S. Anderson, J.L. Repka, G.S. Dick, Explicit treatment of inheritance in dating depositional surface using in situ ${ }^{10} \mathrm{Be}$ and ${ }^{26} \mathrm{Al}$, Geology 241 (1996) 47-51.

[31] J.L. Repka, R.S. Anderson, R.C. Finkel, Cosmogenic dating of fluvial terraces, Fremont river, Utah, Earth and Planetary Research Letters 152 (1997) 59-73.

[32] D.E. Granger, J.W. Kirchner, R.C. Finkel, Spatially averaged long-term erosion rates measured from in-situ produced cosmogenic nuclides in alluvial sediment, Journal of Geology 104 (1996) 249-257.

[33] M. Schaller, F. von Blanckenburg, N. Hovius, P.W. Kubik, Large-scale erosion rates from in situ-produced cosmogenic nuclides in European river sediments, Earth Planet. Res. Lett. 188 (2001) 441-458.

[34] E.M. Pugh, G.H Winslow, the analysis of physical measurements, Addison-Wesley Eds. (1966).

[35] J. Ambert, Les formations alluviales quaternaires de la rive droite du Rhône entre Pont-Saint-Esprit et Avignon, Journées Sc. ANDRA, 20-21 octobre 1997, Rec, 23-25.

[36] J.F Pastre, A. Billard, E. Dubard, M. Faure, C. Guerin, Un horizon téphrique du Mont-Dore dans les loess plio-pléistocènes de Saint-Vallier (Drôme, France), C. R. Acad. Sci. Paris t.323 II (1994) 607-614.

[37] E. Dubard, M. Faure, C. Guerin, Stratigraphie du gisement villafranchien moyen de Saint-Vallier (Drôme) C. R. Acad. Sci. Paris t.318 II (1994) 1283-1286.

[38] M. Bornand, Altération des matétiaux fluvio-glaciaires, genèse et évolution des sols sur terrases quaternaires dans la moyenne vallée du Rhône, unpublished $\mathrm{PhD}$ Thesis, Université de Montpellier, France (1978), 377 pp.

[39] E.T. Brown, R.F. Stallard, M.C. Larsen, G.M. Raisbeck, F. Yiou, Denudation rates determined from the accumulation of in situ-produced ${ }^{10} \mathrm{Be}$ in the Luquillo experimental forest, Puerto Rico, Earth Planet. Res. Lett. 129 (1995b) 193-202.

[40] G.Y. Brocard, P.A. Van der Beek, D.L. Bourlès, L.L. Siame, J-L. Mugnier, Rates of fluvial incision and river response time in periodically glaciated catchments from ${ }^{10} \mathrm{Be}$ cosmogenic dating of fluvial terraces in the french alps, submitted to Earth and Planetary Science Letters (2002).

[41] G. Clauzon, J.P. Aguilar, J. Michaux, Mise en évidence du diachronisme du mur de la formation conglomératique de Valensole (Alpes de Haute-Provence, France): implications géodynamiques, C.R. Acad. Sci., Paris II 304 (1987) 3-22.

*Corresponding author, Tel: +33-1-69156754; E-mail address: siame@geol.u-psud.fr 
[42] M. Cushing, P. Volant, O. Bellier, M. Sébrier, E. Baroux, B. Grellet, P. Combes, T. Rosique, A multidisciplinary experiment to characterize an active fault system in moderate seismic activity area : the example of the Durance fault (South East France), EGS XXII General Assembly, Vienne, Blackwell, Eds.

[43] D.L. Wells, K.J. Coppersmith, New empirical relationships among magnitude, rupture length, rupture width, rupture area, and surface displacement, Bulletin of the Seismological Society of America 84 (4) (1994) 9741002.

[44] E.A. Benedicto, Modèles tectono-sédimentaires des basins en extension et style structural de la marge passive du Golfe du Lion (partie nord), Sud-Est France. unpublished PhD Thesis, Univ. Montpellier II, France, 242 pp.

[45] G.M. Raisbeck, F. Yiou, D.L. Bourlès, E.T. Brown, D. Deboffle, P. Jouhanneau, J. Lestringuez and Z.Q. Zhou - The AMS Facility at Gif-sur-Yvette : Progress, Perturbations and Projects - Nuclear Instruments and Methods in Physics Research B92 (1994) 43-46. 
Table 1 - Site parameters and measured in situ-produced ${ }^{10} \mathrm{Be}$ concentrations

\begin{tabular}{|c|c|c|c|c|c|c|}
\hline SAMPLE & $\begin{array}{l}\text { Latitude } \\
\qquad\left({ }^{\circ} \mathbf{N}\right)\end{array}$ & $\begin{array}{l}\text { Altitude } \\
\text { (m) }\end{array}$ & $\begin{array}{l}\text { depth } \\
(\mathrm{cm})\end{array}$ & $\begin{array}{c}\text { Production } \\
\text { (at/g/y) }\end{array}$ & $\begin{array}{c}{[\mathbf{B e}-10]} \\
\left(10^{5} \text { at./g) }\right.\end{array}$ & $\begin{array}{c}\text { [Be-10] } \\
\text { error }\left(10^{5} \text { at./g) }\right.\end{array}$ \\
\hline \multicolumn{7}{|c|}{ BOIS CLARY VILLAFRANCHIAN TERRACE (LOWER RHONE VALLEY) } \\
\hline VL97-7 & 44.0377 & 127 & 0 & 5.46 & 2.21 & 0.16 \\
\hline CVL97-14 & 44.0377 & 127 & 0 & 5.46 & 2.29 & 0.16 \\
\hline CVL97-11 & 44.0377 & 127 & 45 & 5.46 & 1.34 & 0.15 \\
\hline CVL97-8bis & 44.0377 & 127 & 95 & 5.46 & 0.93 & 0.16 \\
\hline CVL97-5bis & 44.0377 & 127 & 145 & 5.46 & 0.81 & 0.29 \\
\hline
\end{tabular}

MANOSQUE (MOYENNE DURANCE ALLUVIAL TERRACES)

Lower terrace Fz
\begin{tabular}{|l|c|c|c|c|c|c|}
\hline TCARZ97-2 & 43.8473 & 315 & 0 & 6.48 & 0.27 & 0.04 \\
\hline TCARZ97-5 & 43.8473 & 315 & 0 & 6.48 & 0.13 & 0.03 \\
\hline TCARZ97-10 & 43.8473 & 315 & 0 & 6.48 & 0.42 & 0.09 \\
\hline
\end{tabular}

Upper terrace Fy

\begin{tabular}{|l|c|c|c|c|c|c|}
\hline TEDFY97-1 & 43.8482 & 330 & 0 & 6.57 & 0.26 & 0.03 \\
\hline TEDFY97-7 & 43.8482 & 330 & 0 & 6.57 & 0.05 & 0.05 \\
\hline TEDFY97-9 & 43.8482 & 330 & 0 & 6.57 & 3.07 & 0.50 \\
\hline PCAR97-9 & 43.8482 & 330 & 75 & 6.57 & 0.37 & 0.11 \\
\hline PCAR97-7 & 43.8482 & 330 & 130 & 6.57 & 0.24 & 0.09 \\
\hline PCAR97-5 & 43.8482 & 330 & 175 & 6.57 & 0.16 & 0.04 \\
\hline PCAR97-0 & 43.8482 & 330 & 300 & 6.57 & 0.06 & 0.05 \\
\hline
\end{tabular}

Quartz minerals were extracted from alluvial material blanketing the selected fill-terraces. Among the variety of rock-type included in the alluvial material, quartz vein cobbles large enough were preferred to minimize the possibility of clast mobility during soil development. Sampled cobbles were crushed and sieved to extract the 250-100 $\mu \mathrm{m}$ fraction. Sieved samples were then leached with $30 \% \mathrm{HCl}-70 \% \mathrm{H}_{2} \mathrm{SiF}_{6}$ solutions for cleaning, and with a series of four sequential HF solutions to eliminate potential pollution by atmospheric ${ }^{10} \mathrm{Be}$. Cleaned quartz cores were then completely dissolved in HF, and a ${ }^{9} \mathrm{Be}$ spike was added before solvent extraction and alkaline precipitation of Be. Measurements of ${ }^{10} \mathrm{Be}$ were undertaken at the Tandétron AMS facility [45] (Gif-sur-Yvette, France) using NIST ${ }^{10} \mathrm{Be}$ standard (Standard Reference Material $4325,{ }^{10} \mathrm{Be} /{ }^{9} \mathrm{Be}=2.68 \times 10^{-11}, 1986$ August). The analytical uncertainty results from uncertainties based on counting statistics $(1 \sigma)$, conservative assumption of 5 per cent variability in machine response, and a 50 per cent uncertainty in the chemical blank correction.

*Corresponding author, Tel: +33-1-69156754; E-mail address: siame@geol.u-psud.fr 
Figures

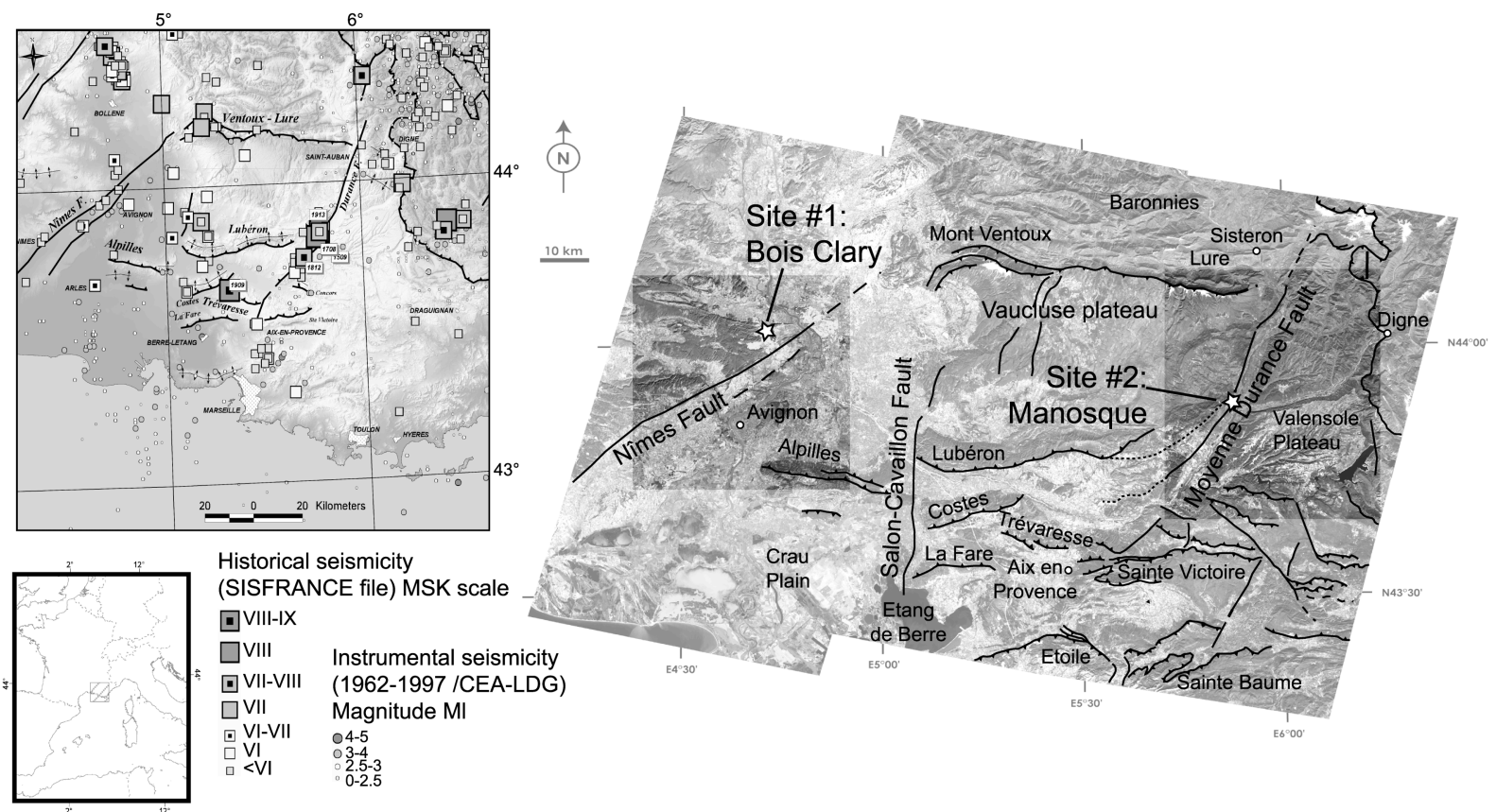

Figure 1

Figure 1 - Left: Regional historical and instrumental seismicity of the Provence domain plotted onto a 50 m-resolution Digital Elevation Model of the Provence. Right: Regional tectonic structures of the Provence domain plotted onto a mosaic of SPOT scenes. The main geological structures are from Champion [6], the MDF segmentation is after Baroux [7]. Stars localise the studied sites. 
A

$\left[{ }^{10} \mathrm{Be}\right]$ at./g( $\left(\mathrm{SiO}_{2}\right)$
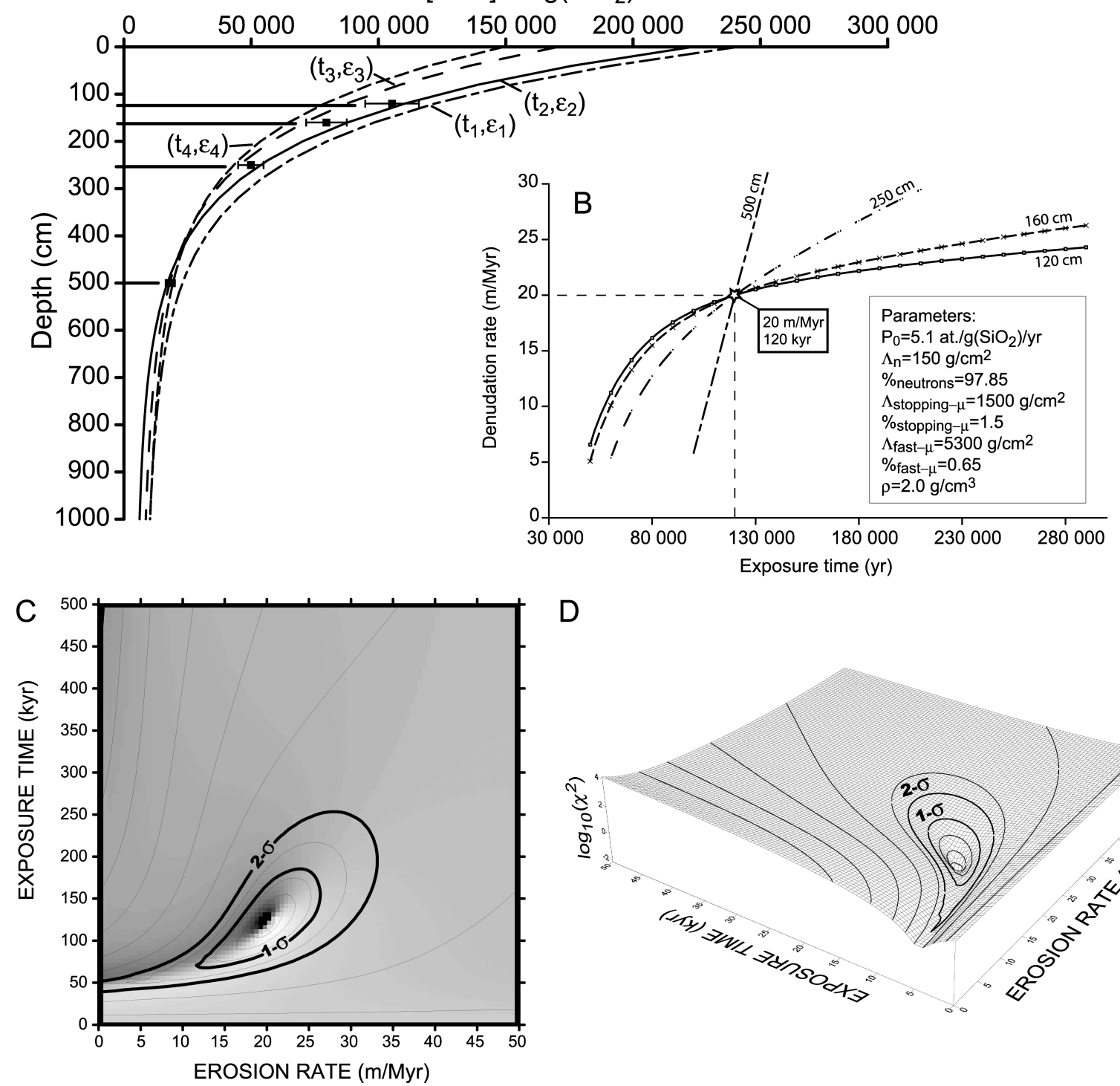

D

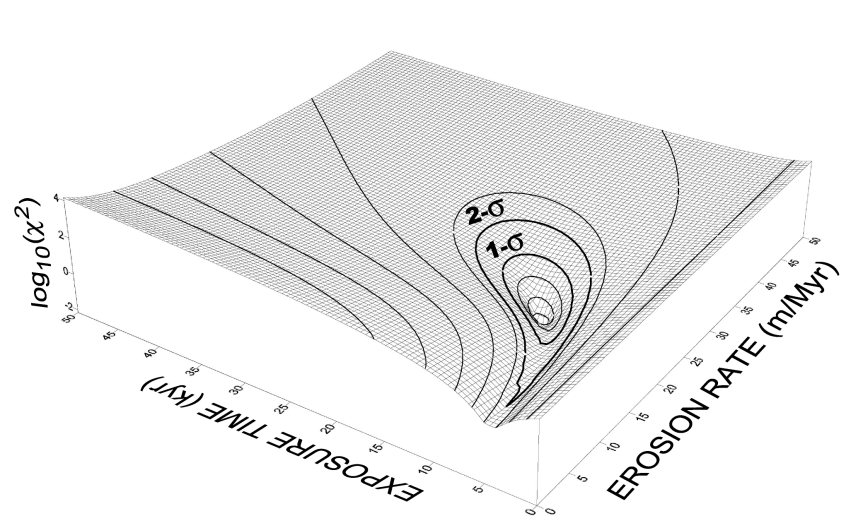

Figure 2

Figure 2 - Case study illustrating the unique solution for a given exponential down-concentration profile. A - Plot of ${ }^{10} \mathrm{Be}$ concentrations as a function of depth for different depths within an alluvial unit of unknown age. B - At each sample depth, one can theoretically compute an infinity of (erosion, time) solutions that explains the sample concentration. In the (erosion rate, exposure time) space, these solutions define pathways. For more than two samples, the intersection of all the pathways yields the model solution. C. Plot of the gridded $\log 10\left(\chi^{2}\right)$ values for an exposure duration ranging from 0 to $500 \mathrm{kyr}$, and for erosion rates ranging from 0 to $50 \mathrm{~m} / \mathrm{Myr}$. D. 3D graph of the gridded $\log 10\left(\chi^{2}\right)$ values for the same exposure duration and erosion rates ranges. Contour lines of constant $\log 10\left(\chi^{2}\right)$ values give the confidence region of the solution at $68 \%(1-\sigma)$ and $90 \%$ 
$(2-\sigma)$, respectively. The model solution is ideally located within a well-defined potential pit of $\chi^{2}-$ values.

A

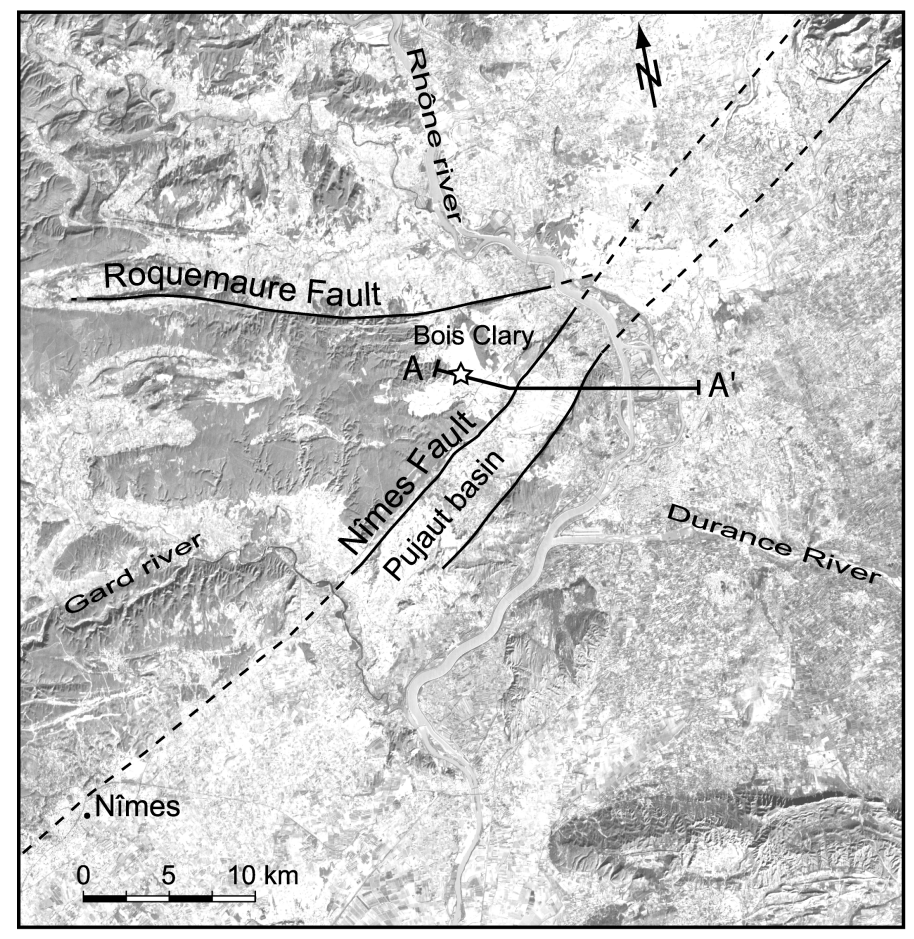

B
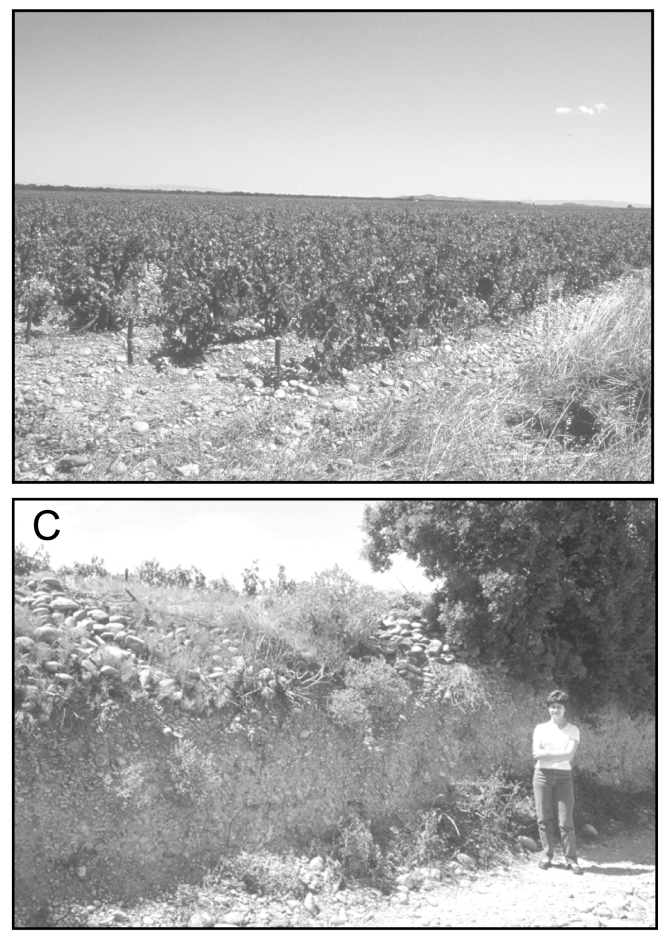

$A^{\prime}$

$\mathrm{E}$

Rhône:

$20 \mathrm{~m}$

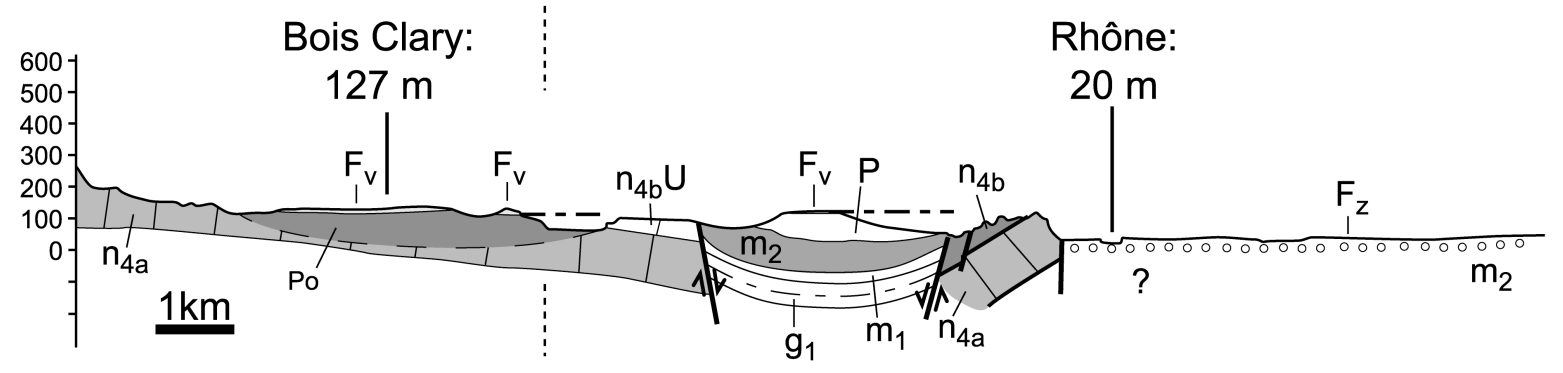

Figure 3

Figure 3 - Structural and geomorphic setting of the Bois Clary alluvial terrace. A - Location of the Bois Clary terrace onto a SPOT image extract centred on the Nîmes fault and the Pujaut basin (modified after Peulvast et al. [8]). B - General view of the surface of the Bois Clary Villafranchian terrace. C - View of the $\sim 2 \mathrm{~m}$ deep anthropomorphic outcrop where the depth profile has been sampled. A-A' - Sketch geological profile (modified after Peulvast et al. [8]): Fz, low fluvial terraces, Late Glacial to Holocene deposits; Fy, intermediate fluvial terraces, Early Late Glacial fluvial deposits; Fx, high fluvial terraces, Middle Pleistocene or older fluvial deposits; Fv, Pliocene-Lower Pleistocene fluvial deposits (Villafranchian I); Po, Pliocene sand; P, Pliocene marl; 
m2, Langhian-Tortonian sand and marl; m1, Burdigalian molasse; g1, Upper Eocene-Lower Oligocenesand, marl, and limestone; n4ab: Barremian bioclastic limestone; n4bU: Upper Barremian, "Urgonian” limestone.

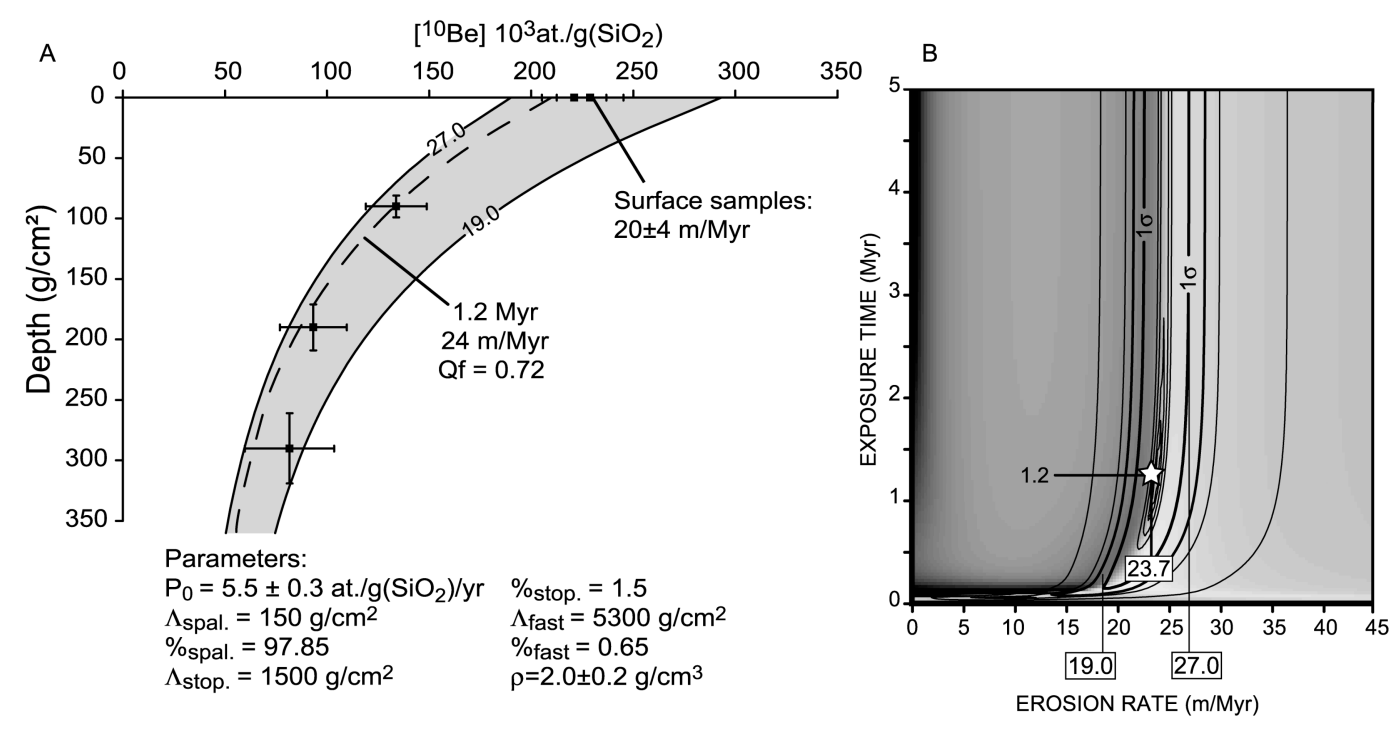

Figure 4

Figure 4 - Khi-square best fit for the Villafranchian Bois Clary terrace. A - Plot of the measured ${ }^{10} \mathrm{Be}$ concentrations as a function of depth with associated uncertainties. Dotted-line represents the modelled exponential decrease with depth for the best-fit (erosion: $24 \mathrm{~m} / \mathrm{Myr}$, time: $1.2 \mathrm{Myr}$, Qf: 0.72) solution. Bold lines correspond to exponential decreases with depth for infinite exposure time (steady-state equilibrium) with erosion rates of 19 and $27 \mathrm{~m} / \mathrm{Myr}$, respectively. B - Plot of the gridded $\log 10\left(\chi^{2}\right)$ values for an exposure duration ranging from 0 to $5 \mathrm{Myr}$, and for erosion rates ranging from 0 to $45 \mathrm{~m} / \mathrm{Myr}$. 

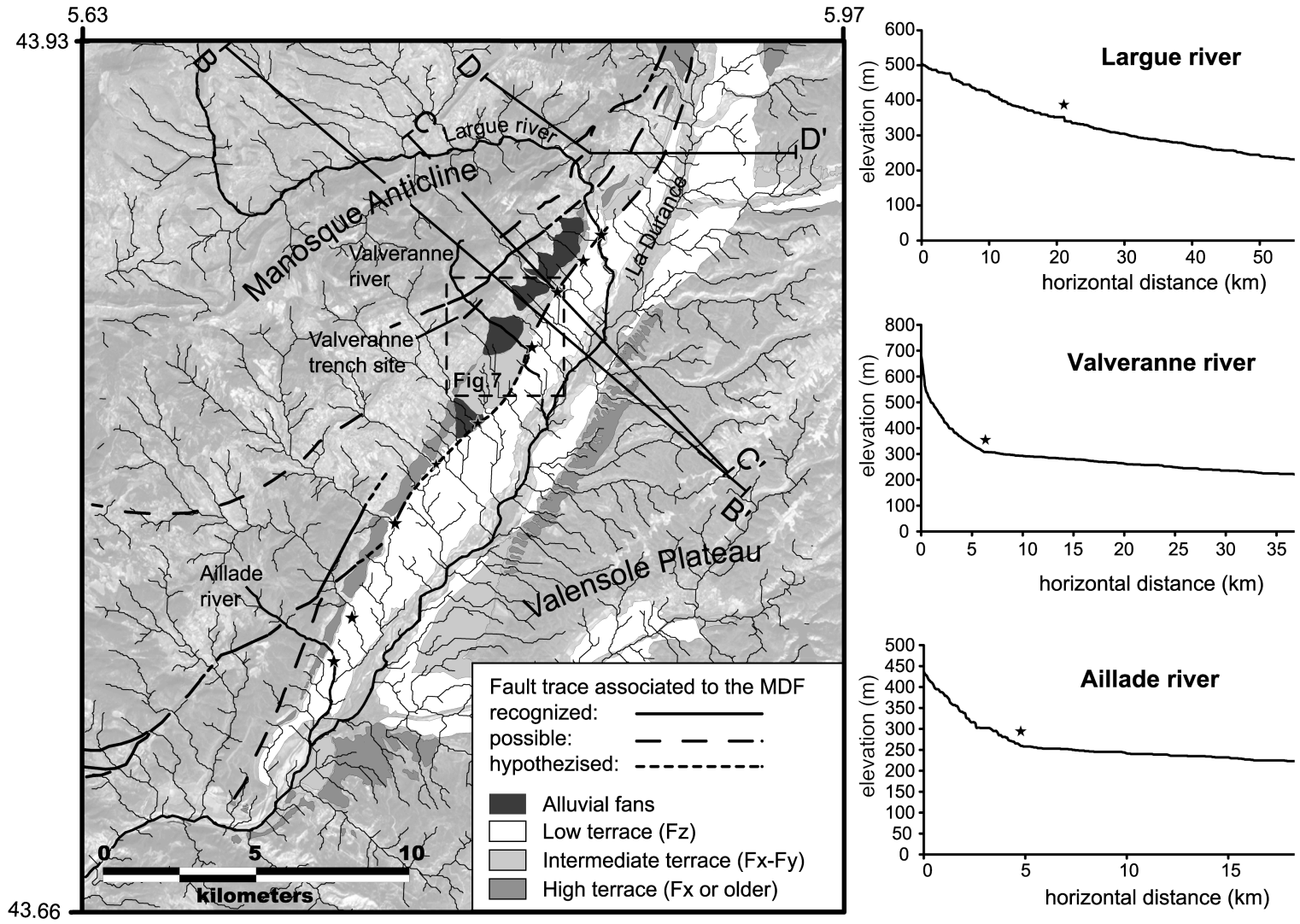

figure 5

Figure 5 - A - Map of the Quaternary alluvial terraces (Fz, low fluvial terraces, Late Glacial to Holocene deposits; Fy, intermediate fluvial terraces, Early Late Glacial fluvial deposits; Fx, high fluvial terraces, Middle Pleistocene or older fluvial deposits) and fault traces associated to the Moyenne Durance Fault. Stars locate the inflection points of the rivers that drain out of the Manosque anticline into the Durance alluvial plain. Geological cross-sections are presented in figure 6 . The box locates the aerial photograph which is used to locate the geophysical survey and the cosmic ray exposure sampling site. B - Topographical profiles of the Largue river and other secondary rivers that drain out of the Manosque anticline into the Durance alluvial plain. Stars correspond to the inflection points mapped on the map. 


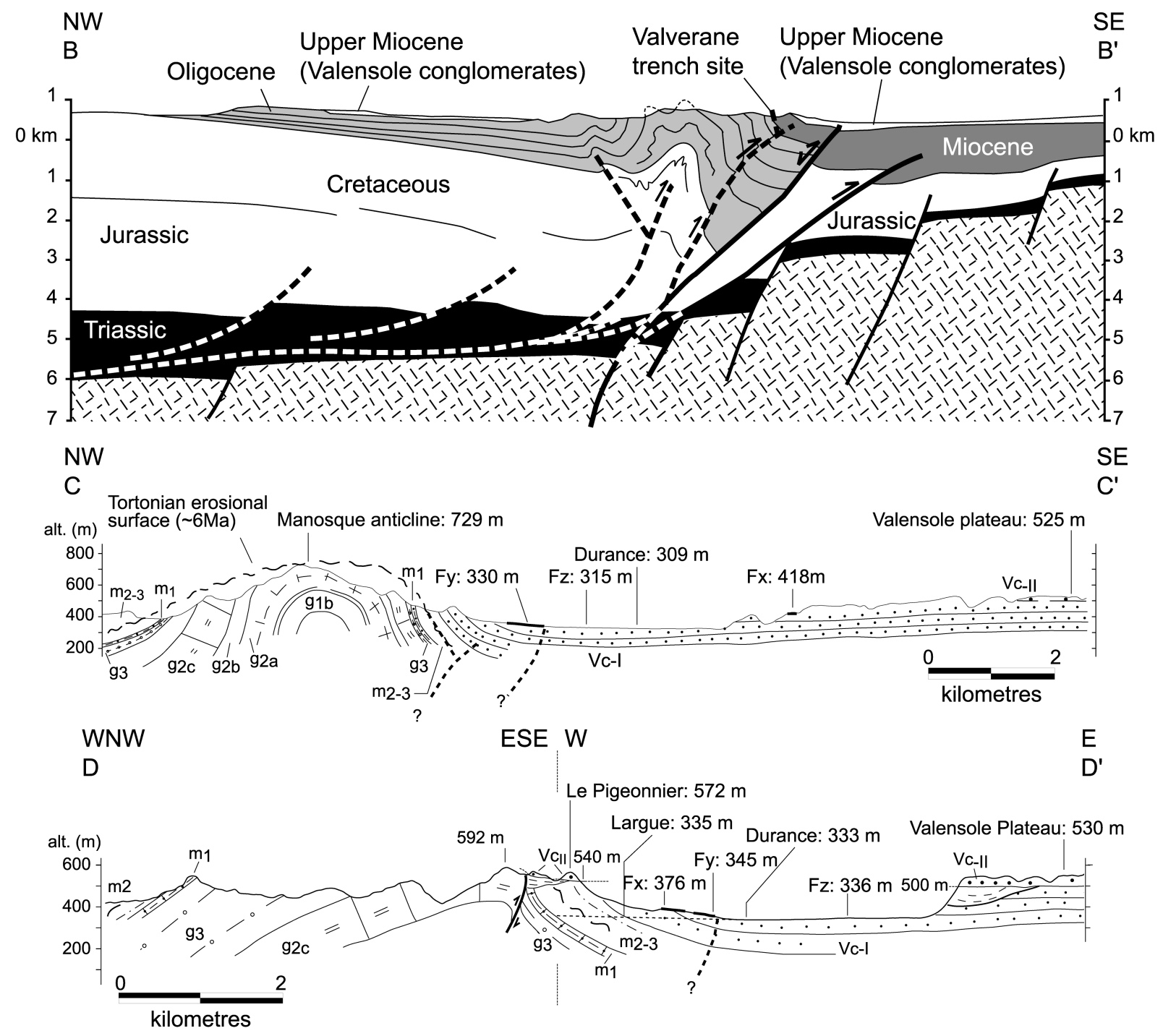

\section{Figure 6}

Figure 6 - Geological profiles across the Manosque anticline and the Moyenne Durance Fault. B-B' Balanced cross-section in the Manosque area (modified after Benedicto [44]). E - Sketch crosssection across the eastern flank of the Manosque anticline. C-C' - Profile across the central part of Manosque anticline (modified after Peulvast et al. [8]). D-D' - Profile across the north-eastern tip of the Manosque anticline (modified after Peulvast et al. [8]). Fz, low fluvial terraces, Late Glacial to Holocene deposits; Fy, intermediate fluvial terraces, Early Late Glacial fluvial deposits; Fx, high fluvial terraces, Middle Pleistocene or older fluvial deposits; bold dots, Valensole II conglomerates; dashes, Pliocene sand and gravel (filling the Messinian palaeovalley); fine dots, Upper Miocene 
Valensole I conglomerates; m2-3, Langhian-Tortonian, sandy molasse; m1, Burdigalian, bioclastic molasse; g3, Upper Oligocene, marl, sandstone and conglomerates next to the fault; g2a1, g2a2, g2b, g2c: Oligocene, alternate layers of limestone, sandstone and marl, conglomerates in the vicinity of the Moyenne Durance fault.
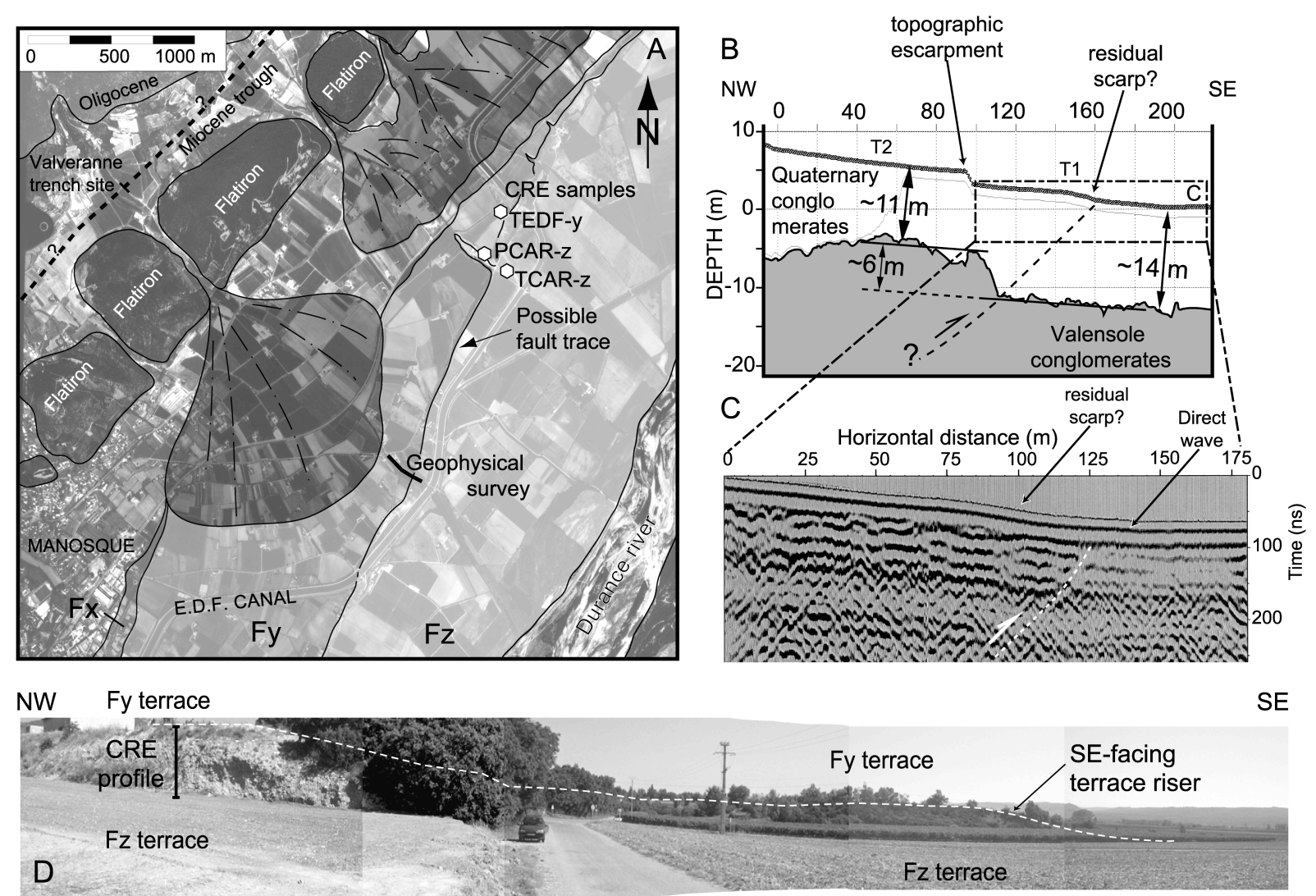

\section{Figure 7}

Figure 7 - A - Quaternary alluvial deposits mapped onto an aerial photograph centred on the studied site showing the SE-facing topographic escarpment, and locating the geophysical profiles, the Valveranne paleoseismological evidence [12] and the alluvial terraces selected for cosmogenic ${ }^{10} \mathrm{Be}$. Sub-surface geophysical data (after Baroux [7]). B - Interpretative sketch of a seismic refraction profile suggesting a $\sim 6 \mathrm{~m}$ vertical offset of the Valensole/Quaternary conglomerates transition. C Ground Penetrative Radar profile corrected for topography. The vertical scale is in time with 100 ns corresponding roughly to 4 meters. D. Panoramic view showing the sampled terrace apparatus near Manosque. 

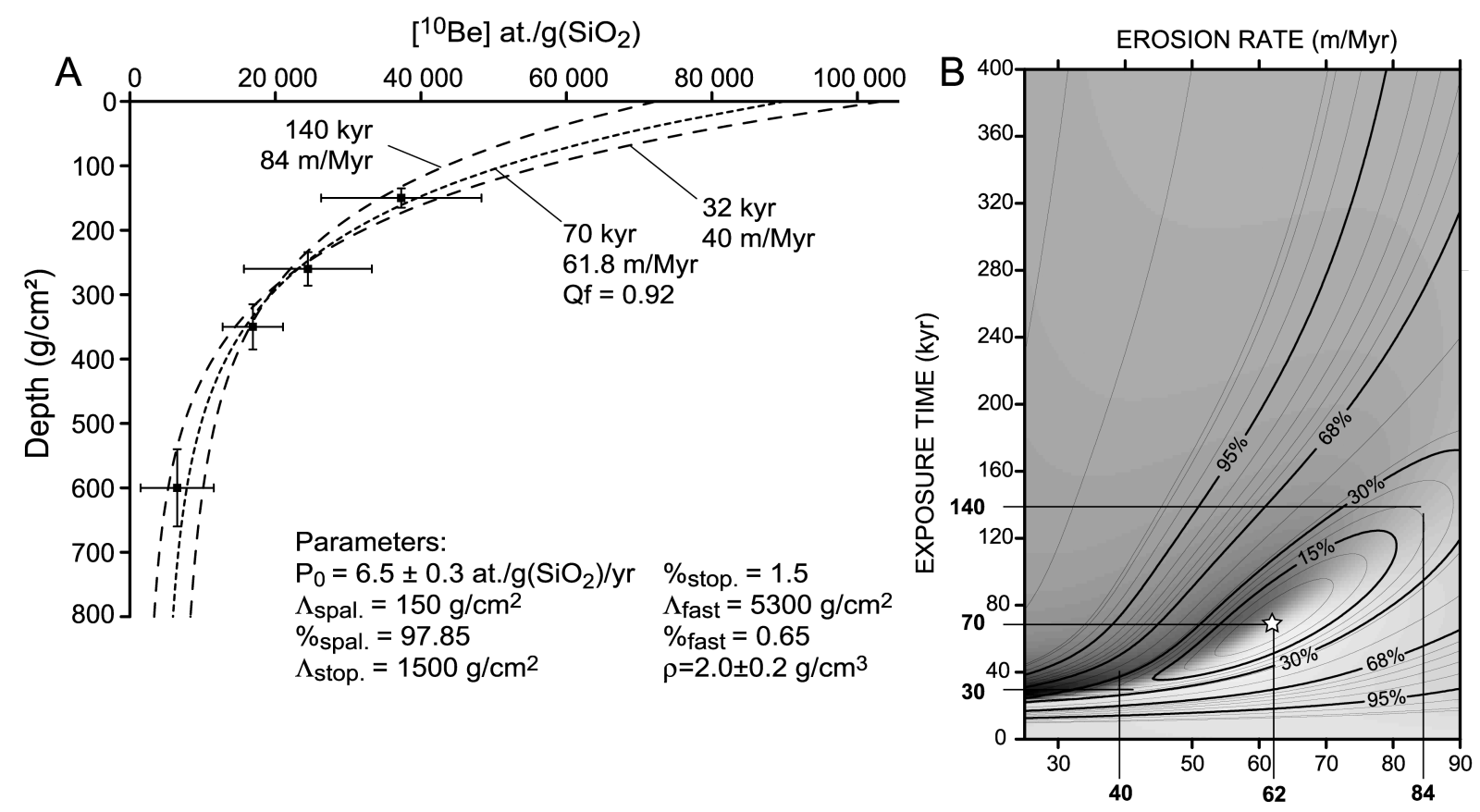

Figure 8

Figure 8 - Khi-square best fit for the Manosque terrace. A - Plot of the measured ${ }^{10} \mathrm{Be}$ concentrations as a function of depth with associated uncertainties. Dotted-line represents the modelled exponential decrease with depth for the best-fit (erosion: $62 \mathrm{~m} / \mathrm{Myr}$, time: $70 \mathrm{kyr}$, Qf: 0.92) and end-member solutions. B - Plot of the gridded $\log 10\left(\chi^{2}\right)$ values for an exposure duration ranging from 0 to $400 \mathrm{kyr}$, and for erosion rates ranging from 25 to $90 \mathrm{~m} / \mathrm{Myr}$. Contour lines of constant $\log 10\left(\chi^{2}\right)$ values give confidence regions of the solution at different levels.

*Corresponding author, Tel: +33-1-69156754; E-mail address: siame@geol.u-psud.fr 